\title{
9 Production Technology of Commercial Epiphytic Orchids for Cut flowers
}

The term "Cut flowers" refers to blossoms or flower buds that are cut with branches, leaves and stems. Fresh cut flowers are highly perishable because they maintain only limited life supporting processes by absorbing water through their stems. They are used for bouquet preparation, decorations, vase arrangements; designs for weddings and funerals; gifts on occasions; informal display to beautify home and public places. Cut flowers are the most important floricultural products in the international flower trade. The most traded flower crops include roses, carnations, chrysanthemums, dahlia, gerbera, gladiolus, gypsophila, liatris, nerine, orchids, poinsettias, achillea, anthurium, tulips and lilies. These flowers are cultivated in open fields or protected structure.

Epiphytes grow on trees or other objects above ground level, but they do not act as parasites. Plants living epiphytically in a tropical rain forest face better light conditions than plants living on the ground level. On top of that, epiphytes are more easily pollinated by flying pollinators. The roots of an epiphyte are developed for a life above soil. For example, they need high air humidity since they often are forced to take most of their water from the air. Together with epiphytic ferns and bromelias, orchids grow and flower on tropical trees. Many orchids growing 'with' a tree have adapted very precisely to the tree's 'behaviour'. For example, when the tree drops its leaves to a period of rest, the orchid does the same thing.

\subsection{Cymbidium (Orchidaceae)}

\subsubsection{Introduction}

Cymbidiums are among the most popular winter and spring blooming semi-terrestrial orchids and originated from tropical and subtropical Asia. This includes North Eastern India, China, Japan, Malayasia, the Philippines, Borneo islands and North Australia, where it usually grows in cooler climates at high elevations. The important Cymbidium growing countries in the world are Australia, New Zealand, Japan, the Netherlands, the USA and England. Cymbidium consists of 70 semi-terrestrial and epiphytic orchid species of tropical and subtropical Asia.

\subsubsection{Botanical Description}

The plants are characterized by short and stout pseudobulbs ensheathed by encircling leaf bases. Leaves are long, ribbon shaped, leathery or soft and lanceolate. The flower spikes develop from the base of the pseudobulbs. 
A plant has three types of bulbs. 1. Old Backbulbs without leaves, which act as a reserve food supply for emergencies. It is advisable to leave one of these on each divided plant. Back bulbs can make new plants but they may take years to flower. 2. Old bulbs with leaves, which support the new growth and may produce flowers for a number of years depending on the variety. When dividing, the plant must retain at least two old bulbs or have one back bulb attached to be able to reflower next year. 3. New leads or bulbs, which are the youngest bulbs on the plant that the flowers and most new growth come from. When dividing, at least 1 old bulb and one back bulb must be retained with this bulb to ensure that the plant may flower the following year.

The spikes are erect, arching or pendulous and arranged with 2 to 15 flowers. The individual florets are $1 \mathrm{~cm}$ to $12.5 \mathrm{~cm}$ across and are of various colours and shades. Cymbidiums are famous for their beautiful spikes derived from species and hybrids. Among the orchids, Cymbidium ranks first and in floricultural crops it accounts for $2.7 \%$ of the total cut flower production.

\subsubsection{Classification}

Cymbidium hybrids are classified into three groups-Standard, Intermediate and Miniature hybrids. Standard and Intermediate hybrids produce 90 to $120 \mathrm{~cm}$ long spikes with 8 to 15 flowers per spike. Miniature hybrids produce green, yellow or brown coloured flowers, $30 \mathrm{~cm}$ tall and each spike contains $30-40$ flowers of 2.5 to $8.5 \mathrm{~cm}$ across. Novelty or Intermediate hybrids have been evolved by crosses between Miniature and Standard hybrids.

\subsubsection{World Scenario}

Cymbidium has been considered the top commercial orchids in Europe for many years. They fetch the highest price in the international markets, with the Asian countries of Singapore and Japan and the Netherlands being the major markets. Cymbidiums imported from the Netherlands fetched as much as US\$ 11.18 per stem in Singapore, and those imported by Japan from New Zealand fetched US\$ 3.33 per stem. As fars as the Dutch Auction market is concerned, the cymbidiums fetched the highest value, averaging Euro cents 331 per stem during 2003-2007 period (Tab. 9.1). East Sikkim has been declared an Agri Export Zone exclusively for production of cymbidium orchids. In Sikkim, more than 250 hybrids of cymbidium orchids are commercially cultivated in an around 25 ha of land and about 5 lakhs spikes are produced annually. 
Tab. 9.1: Average Annual Prices at Netherlands Auction (2003-2007) (Euro cents / stem)

\begin{tabular}{lcccc}
\hline Orchids & $\mathbf{2 0 0 3}$ & $\mathbf{2 0 0 5}$ & $\mathbf{2 0 0 7}$ & Average price \\
\hline Phalaenopsis & 38 & 46 & 37 & 40 \\
Cymbidium (Big bud) & 330 & 334 & 329 & 331 \\
$\begin{array}{l}\text { Cymbidium } \\
\text { (Small bud) }\end{array}$ & 138 & 148 & 140 & 142 \\
$\begin{array}{l}\text { Paphiopedilum } \\
\text { Source CBlMarket }\end{array}$ & 58 & 52 & 63 & 58 \\
\hline
\end{tabular}

Source: CBI Market Survey, The Cut Flowers and Foliage Market in the EU

\subsubsection{Importance and Uses}

Cymbidiums are highly valued for their potential as genetic resources, cut flowers, hanging baskets, potted plants and herbal medicines (Tab. 9.2) (De and Medhi, 2012).

Tab. 9.2: Genetic resources for hybridization

\begin{tabular}{|c|c|}
\hline Name of species & Uses \\
\hline $\begin{array}{l}\text { Cymbidium iridioides, C. eburneum, C. hookerianum, } \\
\text { C. sanderae, C. lowianum, C. tracyanum, C. insigne, } \\
\text { C. erythrostylum }\end{array}$ & Development of standard cymbidium hybrids \\
\hline Cymbidium ensifolium, C. devonianum, C. tigrinum & $\begin{array}{l}\text { Development of miniature cymbidium } \\
\text { hybrids }\end{array}$ \\
\hline Cymbidium atropurpureum, C. finalaysonianum & $\begin{array}{l}\text { Development of cascading cymbidium } \\
\text { hybrids }\end{array}$ \\
\hline
\end{tabular}

\subsubsection{Cut flowers}

Both standard and novelty hybrids are used as cut flowers.

\subsubsection{Potted Plants}

Species like $C$. ensifolium, $C$. aloifolium, $C$. devonianum, C. eburneum, C. lancifolium, C. lowianum and C. mastersii are used as potted orchids. Other miniature orchid hybrids that can be used as potted plants are Autumn Beacon Geyserland, One Tree Hill Solstice Gold B/CSA, Wakakusu Delight, Minneken Khobai, Kusada Fantasy Carioca, Phar Lap, Gladys Whitesell, Summer Love. 


\subsubsection{Hanging Baskets}

Cascading hybrids are ideal for hanging baskets: e.g., Sarah Jean Ice Cascade Ad/CSA, Nicoles Valentine Geyserland HCC/AOS, Dorothy Stockstill Forgotten Fruit.

\subsubsection{Herbal Medicines}

In India, orchids have been used in the indigenous system of medicine since the Vedic period. In general, orchids through out the world are used for curing rheumatism, malaria, tuberculosis, cuts, wounds, burn injuries, asthma, bronchitis and several other ailments.

Tab. 9.3: Cymbidium orchids used in Indian medicine system

\begin{tabular}{lll}
\hline Botanical name & Parts used & Therapeutic uses \\
\hline Cymbidium aloifolium & Rhizomes & $\begin{array}{l}\text { Salep; used as nutrient and demulcent; } \\
\text { as emetic and purgative }\end{array}$ \\
Cym. ensifolium & Rhizomes \& Flowers & $\begin{array}{l}\text { Eye sores } \\
\text { Cym. longifolium }\end{array}$ \\
Cym. giganteum & Pseudobulb & As emetic and demulcent \\
\hline
\end{tabular}

\subsubsection{Stylish Packaging}

These are specially designed to add value to the cut flowers.

Ciliandra: A gift of glass flute containing miniature cymbidium.

Oriental diamond: A fine packaging method for cut cymbidium is designed to add value to delicate flowers and used for special occasions.

Aura of Luxury: A new packaging method for cymbidium for luxury and style.

\subsubsection{Varieties (De, 2014)}

White: Jungfrau 'Snow Queen', Jungfrau 'Dos Pueblos', Camalex, Showgirl 'Cooksbridge', Showgirl 'Marion Miller', Swallow var. 'Takarazuki'

Pink: Lilian Stewart ‘Coronation', Lilian Stewart 'Party Dress’, Orkney ‘Pink Heather', Ensikhan, 'Alpha Orient', Pacific Rose 'Swansea', Soulhunt Series, Valley Paradise 'Shangriila', Rievaulx 'Cooksbridge', Rincon Fairy 'Pink Perfection'.

Yellow: Angelica 'December Gold', Highland Sunset 'Plumpton', Mini Sarah 'Artisan', Hawtescens, Gwen Sherman, 'Arthur Fetzer', San Francisco 'Mona Lisa', Valya Craig 'Sutherland', Luana 'Imperial', 'Pine Clash Moon Venus', 'Valley Legend Steff'

Green: Joyce Duncan 'Susan Hughes', 'R.D. Hughes', Miretta 'Mcbean', Lucense, Tricia Allen 'The Globe', Sparkle 'Late Green', Levis Duke ‘Belle Vista', Sparkle 'Late 
Green', Amsebury 'Frank Slattery', 'Valley Zenith 'Top Spot', 'Madrid Forest King', 'Winter Beach Sea Green'

Red: Chief Joseph 'Pathfinder', Sensation 'Chianti’ 4N, Terama 'Robin,'Barushka 'Dos Pueblos', Khyber Pass 'Rowes Red', James Toya, 'Fire Storm Ruby’, ‘Fire Storm Blaze’ 'Bob Marlin Lucky'

\subsubsection{Growing Requirements}

In India, its cultivation is limited to Sikkim and the surrounding region of West Bengal covering Kalimpong, Darjeeling and Mirik. Other North Eastern states like Nagaland and Arunachal Pradesh are also promoting this flower. Higher elevations of 1500$2000 \mathrm{~m}$ with cool summer night and monsoonal summer rain are ideal for cymbidium cultivation.

\subsubsection{Light}

A full morning sun or bright dappled afternoon shade during summer and full sun in winter is ideal. Mature plants need $50-55 \%$ shade during hot weather. During growing season they require up to 5000-6000 foot candle light, whereas in flowering season up to 2000-3000 foot candle light is needed. Foliages should be yellowish green in colour.

\subsubsection{Temperature}

In general, cymbidiums can tolerate temperatures as low as $7^{\circ} \mathrm{C}$. In the vegetative stage, plantlets grow best at temperature of $18^{\circ} \mathrm{C}$ at night and $24-30^{\circ} \mathrm{C}$ during the day. A temperature of $10-15^{\circ} \mathrm{C}$ is required for initiation of flower spikes. During the winter season (Late October to late February) a temperature of $7-12^{\circ} \mathrm{C}$ at night and $18-24^{\circ} \mathrm{C}$ during the day is maintained. Miniature hybrids can withstand temperatures $5^{\circ} \mathrm{C}$ higher than standard cymbidiums.

\subsubsection{Propagation}

Cymibidiums are propagated sexually through seeds and asexually through division or backbulbs. Division means splitting the plants into two to three parts each with one new shoot, and each will produce an individual plant. Propagation through back bulb is a slow process which will take three to four years to give a flowering size plant.

Tissue culture is the only way to produce millions of disease free and true to the type plants in the shortest time. In this method, callus (amorphous masses of cells), meristems and organs (root, leaf, flower, embryo, ovary, fruit, seeds, etc.) are isolated and cultured aseptically in a laboratory and supplied with defined media containing sugars, inorganic salts, vitamins and growth regulators. 


\subsubsection{Watering}

In Cymbidium, watering is required year round to keep the pseudobulbs green and smooth. The frequency of watering is given below.

Summer: 2-3 times per week

Autumn: Once or twice per week

Winter: Once per week

Spring: As Autumn season

\subsubsection{Relative Humidity}

An optimum range of relative humidity is $50-80 \%$ and important for good growth and flowering. During hot weather, misting down the plants and the surrounding floors and benches maintains humidity, which prevents crinkling of leaves.

\subsubsection{Air Circulation}

Fresh air and good circulation are essential for orchid production. Leaves should move gently in a light breeze.

\subsubsection{Feeding}

Cymbidium orchids should be fed about once every two weeks. A foliar feeding of 0.2-0.3\% NPK mixture is effective and applied in the following manner.

Spring season: $\quad 30: 10: 10$

Summer season: 19:19:19

Autumn season: 10:30:20

Pre-harvest foliar sprays with micronutrient mixture $(0.05 \%)$, glucose $(0.1 \%)$ and mustard cake ( $1 \mathrm{~kg} / 50$ litres of water) were found promising in terms of number of inflorescence/plant (4 to 6) and number of flowers/spike (8 to 10) followed by $\mathrm{GA}_{3}(50 \mathrm{ppm})$ and cow urine (1:20). Do not feed your cymbidium once it has started flowering.

\subsubsection{Potting and Repotting}

Cymbidiums prefer a coarse compost containing bark, cocopeat, cocochips, leaf mould, sawdust, brick pieces for development of new shoots and good pseudobulb growth. The compost should be very light, slightly acidic in reaction with a $\mathrm{pH}$ range of 5.5-6 and with good drainage properties and water holding capacity. In Cymbidium, the potting mixture combinations, cocochips + cocopeat + brick pieces + chopped fern leaves (3:3:1:1) followed by cocochips + cocopeat + brick pieces + slow release fertilizer (3:3:1:1) were found effective for good pseudobulb growth and flowering. Repotting is required every 2-4 years as indicated by the bulbs filling the pot or breaking 
down of potting mixture and if a plant is not able to produce 1-2 new bulbs each year from each bulb that grew the previous year.

\subsubsection{Planting}

It is advisable to begin at the end of February or beginning of March which will create a congenial environment for early establishment of the plant and thus better growth and development. It is a healthy practice to culture Cymbidiums in pots of $10^{\text {" dia- }}$ meter and 18" height. The pots should be placed at spacing of $60 \mathrm{~cm} \mathrm{x} 60 \mathrm{~cm}$, which will accommodate about 3 pots $/ \mathrm{m}^{2}$ (gross). The total number of plants will be about 30,000 / ha. These must be cultured under shelter by providing poly-cover to obtain quality blooms. Some shading (about 30\%) is essential during the blooming time for proper colour development of flowers and during the young plant stage. Cymbidium pots are kept on 2 to 3 feet high beds.

\subsubsection{Training}

Cymbidiums may be trained with bamboo sticks and yoyo to keep the spikes in upright position.

\subsubsection{Harvest}

The orchid flowers should be harvested at the proper stage to achieve quality flowers and maximum vase life. Morning is the best time for harvesting. Flowers are cut sharply with a knife or secateur and dipped immediately in a bucket of water. In most of the commercial orchids, the optimum harvesting stage is fully opened and mature flowers. A matured healthy plant in a 10" pot under good management will produce about 4-6 flowers per year. A healthy well grown orchid will produce flowers spikes every year and a plant 10 years old can produce from 10 to 20 flower spikes.

\subsubsection{Insects Pests and Diseases}

\subsubsection{Insect Pests}

Mites, thrips, scale insects, aphids, mealy bugs, grass hoppers and shoot borers are common insect pests of Cymbidium. All active stages (nymph and adult) of mite feed on undersurface of leaves and flowers by sucking the cell sap from the epidermal layer, especially along with the midrib and the base. The loss of cell sap causes yellowing of leaves. Sulphur, 3\% wettable or colloidal, satisfactorily controls the nymph and adults.

There are five predominant species of scale insects viz., ti scale, Pinnaspis buxi, florida red scale, Chrysomphalus aonidum; lecanium scale, Lecanium sp; soft brown 
scale, Coccus hesperidum and boisduval scale, Diaspis boisduvali which cause damage on orchids round the year. Both the stages of scale insects suck the cell sap from leaves, pseudobulbs, flower buds and flowers causing yellowing of leaves, vigor loss and stunted new growth. In the case of heavy infestation, infected plants become deformed, and sticky honeydew is excreted which attracts sooty mould on which dust particles deposit resulting in a negative effect on the rate of photosynthesis. Chemicals like imidacloprid 17.8 SL @ 0.003\%, acephate 75 SP or carbaryl 50WP or monocrotophos 36EC @ 0.03-0.05\% can be used against aphids, scale insects and mealybug.

Two species of aphids like yellow aphid, Macrosiphum luteus and black aphid, Toxoptera aurantii mainly cause damage to orchids. The nymphs and adults suck the cell sap usually from new flower spike and foliage. They also excrete honeydew on which sooty mould develops and affects photosynthesis. Thrips, Dichromothrips nakahari suck the cell sap from tender portion of plants and on leaves, it become discolored and shrivels. Both young and adult mealy bugs (Pseudococcus sp) suck the cell sap from the leaves and petioles or any joint portion of plants and as a result of that plants become weakened. Grass hoppers (Hieroglyphus banian) feed on young leaves, un-opened flower buds and flowers by cutting irregular shape with their biting and chewing mouth parts, and ultimately flower quality is affected.

\subsubsection{Diseases}

Black rot, Crown rot or heart rot (Pythium ultimum, P. splendens, Phytophthora palmivora and P. parasitica): Water soaked small brown spot on the aerial parts of plants, which quickly turn black. Fungicides spray viz Captan @ 2 g/l or Zineb @ 2 g/1 water controls it.

Anthracnose (Colletotrichum gloeosporioides and C. orchidacearum): Initial symptom appears as a small oblong to circular oval, sunken and reddish brown to dark brown or gray coloured spots. Die back of leaves are also observed if the leaf tip is attacked. Spraying of Carbendazim (Bavistin) @ $1 \mathrm{~g} /$ liter in 10 days interval checks the disease.

Blossom Blight (Botrytis cinerea): The pathogens produce numerous small dark spots on petals, especially on older flowers. Sometimes shot hole effect is found on infected flower petals. Spraying with Bavistin @ 1g/l liter or indofil Z @ 2g/liter at 7 days intervals are effective.

Bacterial soft rot (Erwinia carotovora pv. carotovora and E. chrysanthi): Deep grayish grey lesions on leaves. It causes leaf spot, soft rot and stem rot with fishy smell. Treating of infected plants with streptomycin or Oxytetracycline solution before planting checks the infection.

Cymbidium mosaic virus (Cymbidium mosaic potexvirus): The virus produces variable symptoms on different hosts. It produces mild or severe mosaic symptoms followed by necrosis. Start with certified and virus free plant material, proper sterilization of tools used in cultural practices, proper distance among plants has to be main- 
tained to avoid virus infection, proper sanitation. Keep growing area free from plant debris. Quarantine new plants and control insect vectors are remedial measures.

Odontoglossum ringspot virus (Tobamovirus): It produces ringspot on Odontoglossum grande and diamond mottle symptoms. Start with certified and virus free plant material, proper sterilization of tools used in cultural practices, proper distance among plants has to be maintained to avoid virus infection and maintain proper sanitation. Keep growing area free from plant debris. Quarantine of new plants and control of insect vectors are remedial measures.

\subsubsection{Post-harvest Management}

A good quality cut flower of an orchid should have the following characteristics

- Minimum eight standard blooms per stem

- Flowers must be cleaned, evenly coloured and free from physiological disorders

- Stem must have flowers evenly arranged and around the stem.

- Two third of the stem should be covered with the flowers.

- Flowers must have a firm texture and a luminescent sheen

- Stems must be firm when held up

- The minimum base diameter of the stem should be of $10 \mathrm{~mm}$

\subsubsection{Stage of Harvest}

In Cymbidium, flowers having $75 \%$ bloom stage or two buds opened stage with the spike length of $60-90 \mathrm{~cm}$ are harvested.

\subsubsection{Grading}

Cut spikes of Cymbidium orchids are graded based upon their classes, number of flowers per spike and spike length (Tab. 9.3).

Tab. 9.3: Grading of Cymbidium cut flowers

\begin{tabular}{llll}
\hline Category & Grade & Flower Count & Spike length \\
\hline Standard & AAA & $12-15$ & $1.25 \mathrm{~m}$ \\
& AA & 8 & $90 \mathrm{~cm}$ \\
\hline Miniature & XL & $>15$ & $65 \mathrm{~cm}+$ \\
& L & $12-14$ & $55-64 \mathrm{~cm}$ \\
& M & $8-11$ & $40-54 \mathrm{~cm}$ \\
& S & $<5$ & $30-39 \mathrm{~cm}$ \\
\hline
\end{tabular}




\subsubsection{Packing}

After harvest the flower stems, are bunched into 5 or 10, wrapped in a specialized polythene cover and at the base of the stem a slant cut is made with a sharp knife. The stem bottom is inserted in a plastic plug containing clean water. This will keep the flowers fresh during transportation. In absence of the plug, a moistened cotton wrapped with a piece of polythene can do the job for domestic market. After plugging or wrapping with moistened cotton, the flower stems are placed in corrugated boxes and readied for dispatch to the market.

\subsubsection{Storage}

The cut spikes can be stored at 0.5 to $5^{\circ} \mathrm{C}$ for 14 days under dry.

\subsubsection{Floral Preservatives}

In the Cymbidium hybrid 'Red Princess' pulsing with 5\% sucrose increases vase life up to 56 days followed by sucrose at 8\% (54.78 days). In Cymbidium, 1-MCP and AVG are superior to STS in prolonging the vase life of cut flowers. In Cymbidium hybrid, 'Red Princess', 75\% open flowers with 200 ppm 8-HQS showed highest vase life along with $100 \%$ opening. In Cymbidium 'Ensikhan' and 'PCMV', 4\% sucrose +100 ppm salicylic acid and 4\% sucrose $+100 \mathrm{ppm} \mathrm{Al}_{2}\left(\mathrm{SO}_{4}\right)_{3}$ are used as bud opening chemicals. $2 \%$ sucrose +200 ppm 8-HQS is also used as holding solution.

\subsection{Dendrobium (Orchidaceae)}

\subsubsection{Introduction}

Dendrobiums are popular flowering potted plants and cut flowers around the world due to their floriferousness, wide range in flower color, size and shape, year round availability and lengthy vase life. Hawaii, California and Florida are major potted Dendrobium growing regions in the United States. In the Netherlands, production of potted orchids is now 40 to 50 million units with Dendrobium increasing in popularity. Imports from Thailand, the world's largest exporter of tropical cut orchids and second largest supplier to the EU, accounted for $22 \%$ of supplies to the EU. Thailand holds a particularly strong position in Dendrobium orchids.

\subsubsection{Botanical Descriptions}

Dendrobium consists of 1600 species of sympodial epiphytic orchids. The genus is characterized by long pseudobulbs or canes with soft leaves on the entire length or in 
some species, pseudobulbs are short or swollen terminating in two coriaceous leaves. The pseudobulbs are of four types, cane woody (a), cane cylindric (b), cane clavate fleshy (c) and bulbous round (d) (Tab. 9.4) (De et al, 2013).

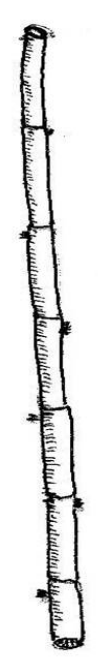

(a)

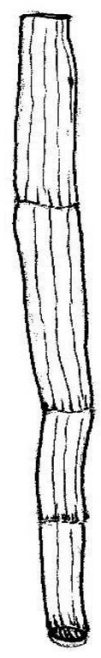

(b)

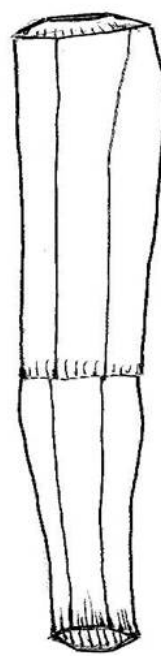

(c)

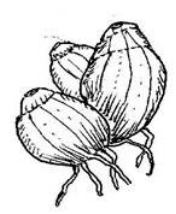

(d)

Tab. 9.4: Nature of pseudobulb in Dendrobium

\begin{tabular}{ll}
\hline Characteristics & Example varieties/species \\
\hline Cane woody & $\begin{array}{l}\text { Den. gibsonii, Den. bensoniae, Den. aphyllum, Den. ruckeri, Den. } \\
\text { aduncum, Den. cathcartii }\end{array}$ \\
Cane cylindric fleshy & --- \\
Cane clavate fleshy & $\begin{array}{l}\text { Den. primulinum, Den. nobile, Den. parishii, Den. pendulum, Den. } \\
\text { loddigesii, Den. 'Bangkok Blue', Den. 'Big White Jumbo', 'Den. 'Thongchai } \\
\text { Gold', Den. 'Erika', Den. 'Triple Pink', Den. 'Madam Pink' } \\
\text { Bulbous round }\end{array}$ \\
\hline
\end{tabular}

The leaf size ranges from $2.5 \mathrm{~cm}$ to $40 \mathrm{~cm}$, thick, and are deciduous or evergreen. In some groups, the flowers are joined in pairs or three on small peduncle on the entire length of the pseudobulbs, with caduceus leaves. In some species, with persistent leaves, the flowers are grouped in pairs or threes or alternately closely set, forming 
erect or pendent thyrses. In another group, flowers are generally solitary and small, arising from the axils of leaves. The inflorescences are terminal or subterminal and arranged with one to several dozens of flowers with extremely diverse dimensions, size and ranges of flower colour.

\subsubsection{Importance and Uses}

Dendrobiums are popular for cut flowers and for interioscaping. They are also valuable as pot plants or hanging baskets. Some species are hanged on the walls or on tree branches to cover the bare walls and branches. The dried stems of Dendrobium nobile are used for making herbal medicines. Dendrobium enhances salivation and is used for the treatment of dry mouth, dry coughs and severe thirst. Flowers could be used to cure eye ailments. The tonic made from Dendrobium nourishes stomach, lungs and kidneys. The plant is effective in treating pulmonary tuberculosis, impotence and anorexia. The pulp of pseudobulb is applied to boils and pimples, and the juice of the plant is used to relieve fever. Dendrobium blossoms are the most common genus used in cooking. In Thailand, these edible flowers are dipped in butter and deep fried while many European cooks garnish desserts and cakes with them. The starchy stems of Den. speciosum are roasted and eaten.

\subsubsection{Hybrids (De, 2014)}

White: 'Snow White', 'Pagoda White', 'Emma White', 'White Surprise', 'Jacquelyn Concert x Walter Oumae', 'Kasem White', 'Big White 4N', 'Big White Jumbo', 'White 5N'. Blue: 'Vorawit Blue', 'Lee Chong Blue’, 'Kultana Blue', 'Kiyoshi Izumi’, ‘Blue Fairy’, 'Lee Chong Blue', 'Bangkok Blue'.

Pink: 'Chiengmai Pink', 'Ekapol Panda', 'Jisu’s Star', 'Juree Red', 'Kiilani Stripe’, 'Long Champ', 'Penang Sugar', ‘Sagura Pink', 'Miss Singapore', 'Madam Pink', ‘Sonia-16', 'Ear Sakul', 'Candy Stripe Pink', 'Sonia-17’, 'Sonia-28', 'Dr. A. Abraham'.

Yellow: 'Sri Siam', ‘Swan Lake', ‘Thongchai Gold', ‘Bonchoo Gold', ‘Sarifa Fatima’.

Green: 'Daangsaard', 'Kanjana Green', 'Green Mist', 'Little Green Apples’.

Red: 'Meike Beauty', 'Pathum Red x Sabin', 'Little Lolita', 'Cleopatra', 'Diamond Star', 'Fireball', 'Kating Daang'.

Interspecific hybrids: 'Australian Lemon Pepper', 'Jiali Paradise', 'Womad', 'Green Elf', 'Memoria Dipper Nishi', 'Falcan', 'First Star', 'Falcan', 'Mini Snowflake', 'Scotts Valentine', 'Dounan Spicy', 'Black Gold', 'Winter Frost', 'Peng Seng', 'Silver Wings', 'Aminah Khatum', 'Bruce Gorden', Green Mist', ‘Aussies Queen', 'Sweet Phurichaya', Big Alex', 'Carly Hera', 'Pink Glow', 'Molly's Angel', 'Go Secret'.

Inter-varietal hybrids: 'Candy Smile', 'Angel Moon', 'Million Gold', 'Liberty Girl', 'Asian Smile', 'Happy Holiday’, 'Happy Smile', 'Pop Eye’, 'Sunny Bird', 'Wonder 
Rabbit', 'Sunny Bird', 'Peach Blossom', 'Long river Giant', 'Sally Fiesta', 'Rudkin', 'Ice Storm', 'Genting Melody’, 'Hawaiian Twinkle', 'Sea Sky’, 'Singa Beauty’, 'Arthur Reserve', 'Green Wonder', 'Open Heart Leaf', 'Rising Star', 'Fairy Star', 'Nice Boy Wanda', 'Burbank Candy’, ‘ Burnt Orange', 'Justine’.

Variety-species hybrids: 'Bright Angel', 'Blue Rain', 'Samson Toy', 'Margaret Thompson', 'Third Eyes Vision', 'Rods Eagle', 'Spider Lily', 'Sylvester', 'Paradise Fortune', 'Sky Mirror', 'Butter Fly Dawn', 'Island Snow', 'Australian Idol', 'Fine Ford', 'Half Moon Bay’, ‘Special Bride’, ‘Two Kings', ‘Juliette Copper’, 'Genting Lipstick', 'Singa Kagoshima', Jairuk Spin'.

\subsubsection{Growth and Physiology}

Like other flowering plants, orchids also have to attain a certain stage of growth and fulfill the energetic demand to initiate flowering. It may vary from 3 years to 7 years depending upon the type of species and hybrids. Orchid pseudobulbs are engaged in the control of physiological processes that are important for growth and survival. The ability to store water, minerals and carbohydrates in the pseudobulb has greater impact for survival in the harsh and nutrient limited epiphytic biotope. Pseudobulb photosynthesis recycles respiratory carbon that would contribute positively to whole plant carbon economy. There are significant variations in the content of carbohydrates in pseudobulbs and flowers and chlorophyll content in leaves among different hybrids. Reducing sugar analysis was carried out in the Dendrobium hybrid 'Thongchai Gold', where three stages of flowers, specifically opened flowers, half opened flowers and bud, were taken for analysis. It was found that the opened flower contains $29.00 \%$, half opened flower contains $28.25 \%$ and buds contain $16.17 \%$ of reducing sugars (De et al, 2013).

\subsubsection{Cultivation}

\subsubsection{Temperature}

The cool growing Dendrobium orchid group thrives well in temperatures ranging between 10 and $24^{\circ} \mathrm{C}$. The intermediate Dendrobium orchid prefers a temperature range of $14-26^{\circ} \mathrm{C}$ whereas the warm growing Dendrobium orchids prefer 16 to $30^{\circ} \mathrm{C}$. The warmer group species like Dendrobium phalaenopsis, Den. gouldii, Den. biggibum, Den. antennatum and Den. discolor bloom at night temperatures above $16^{\circ} \mathrm{C}$ and the cool growing species such as Den. lindleyi, Den. aggregatum, Den. parishii, Den. pierardii, Den. densiflorum, Den. chrysotoxum and Den. anosmum perform well at night temperature of $10^{\circ} \mathrm{C}$. Low day temperature causes leaf yellowing, defoliation and reduces vegetative growth, while higher temperatures delay flower bud development. Low temperature and short days could change the concentration of endogenous growth regulators leading to the induction of flowering in sympodial orchids. 


\subsubsection{Light}

Most orchids generally prefer indirect or filtered light. Although it varies by species, growth habit and habitat, as the rule of thumb, 50\% shading is advised for most of the commercial orchids. Under enough light, orchid plants have short, plump stems with bright green leathery leaves, while too much light causes yellowing, stunting and scorching of plants, and too much shade causes darker green, soft and succulent leaves with thin and spiny stems. All types of Dendrobium orchids require warm bright light (2500-3000 foot candles). They should get at least 12-14 hours of light each day year round.

\subsubsection{Propagation}

Conventionally, Dendrobiums are easy to propagate through keikis that produce along old canes or by division of pseudobulbs. 10-12 cm long cuttings also can be taken from a healthy, older and leafless cane keeping three nodes on each cuttings and placed in moist sphagnum moss for rootings. Commercially, Dendrobium hybrids are usually either seed-propagated or clonally propagated through tissue culture of apical and lateral buds that proliferate as protocorm like bodies.

For seed propagation, green capsules are surface sterilized and seeds are dropped on a basal salt medium containing $15 \%$ coconut water and $2 \%$ sucrose at $\mathrm{pH} 4.8$ to 5.0 for germination. Three months after sowing, seedlings are transflasked with 75 to 100 plants per $500 \mathrm{ml}$ flask in a salt medium containing $15 \%$ coconut water, $2 \%$ banana powder, and 1\% sucrose at $\mathrm{pH}$ 4.8-5.0.

\subsubsection{Atmosphere}

Fresh air and good circulation are essential for orchid production. Full of continual light breezes make a good source carbon dioxide for photosynthesis.

\subsubsection{Fertilization}

Orchids are light feeders and require nitrogen from the beginning to two-thirds of their life cycle. During rest periods, they do not need any fertilizers. During flower initiation and inflorescence development, plants are fed with less nitrogen, more phosphorus and potassium. During the blooming time, a small level of nitrogen and phosphorus and high levels of potassium are maintained. In orchids, foliar feeding is found to be ideal. Frequent application of fertilizers in low concentrations is the best way of feeding orchids. A concentration of 0.2 to $0.3 \%$ of 30:10:10 (N:P:K) at vegetative stage and 10:20:20 (N:P:K) at blooming stage are applied for quality flower production. Sometimes, fresh coconut water, diluted cow urine is also useful as foliar sprays. 


\subsubsection{Potting Mixture}

The potting medium of Dendrobium orchids should be loose, friable as well as well drained. A potting medium consisting of charcoal, brick pieces and coconut fibre in equal proportions is ideal for vegetative growth and flowering of epiphytic orchids like Aerides, Dendrobium etc. Under low humid conditions (30\%), plastic pots with a mixture of bark/perlite/sphagnum moss or osmunda are used. Under average humidity (35-50\%), it is advisable to use plastic pots with a mixture of bark and sphagnum moss. Under high humidity (55\% and above), clay pots are used with bark, stone culture, charcoal or tree fern. In Dendrobium, among potting mixtures, cocochips + cocopeat + leaf mould + brick pieces (4:1:2:3) showed longevity on plants in Den. 'Ear Sakul'(71 days) followed by Den. 'Triple Pink' (70 days) and Den. 'Thongchai Gold' (69 days).

\subsubsection{Watering and Humidity}

Most orchids are damaged by overwatering rather than under watering. Overwatering leads to root rot and many other diseases. Most orchids prefer water of $\mathrm{pH}$ 5.06.5. Watering with lower or higher $\mathrm{pH}$ or with high levels of dissolved minerals can hamper nutrient uptake. Frequent watering is essential under high sunlight and high temperature conditions. Plants in small containers dry out more quickly than in large containers. Plants in earthen pots require more watering than plants in plastic pots. A hanging plant, since it has better aeration, needs more frequent watering than one in a pot. More frequent watering is also necessary for fresh potting materials. Watering should be practiced either in the morning or in the afternoon. Potting materials like coconut husk, tree fern etc., having more moisture retention capacity, need less water and less frequently. The single dominant factor that affects the cultivation of orchids is humidity, which should be as high as $50-75 \%$. It varies species to species depending upon habit of growth, light, temperature and ecotypes. As rule of thumb, in high temperature, humidity should be kept high. Provisions of misting units or foggers or even humidifiers will ensure adequate humidity. Standing water beneath the benches may be kept to improve humidity.

\subsubsection{Repotting}

Orchid plants require repotting if there is no space left in the pots for new growths and if the substrate has decomposed or roots are rotting. Timing is the most important part of good repotting. The best time for repotting of an orchid is when new growth and new roots are just beginning to form, before those new roots reach even $1 \mathrm{~cm}$ long. In most of the orchids, it occurs right after flowering. It shows that repotting should be done between February and June. 


\subsubsection{Application of Growth Regulators}

Experimental evidence has shown that photoperiod and low temperature modify the concentration of endogenous growth regulators. The combined application of $\mathrm{GA}_{3}$ and BA improves inflorescence length and reduces percentage of abnormal flowers. In the Dendrobium hybrid 'Thongchai Gold' maximum flower spikes were found in drenching followed by morning and evening spray. Spike length was found to reach maximum in morning spray with $\mathrm{GA}_{3} 200 \mathrm{ppm}(46 \mathrm{~cm})$ while in evening spray with $\mathrm{GA}_{3} 100 \mathrm{ppm}$ spike length was $43.6 \mathrm{~cm}$ and in morning spray with $\mathrm{GA}_{3} 100 \mathrm{ppm}$, spike length was minimum (42 cm). In Dendrobium hybrid, 'Emma White', treatment with NPK 20:20:20 with Ca, Mg and $\mathrm{Mn}$ along with $\mathrm{BA} 10 \mathrm{ppm}$ and $\mathrm{GA}_{3} 100 \mathrm{ppm}$ increased the number of leaves (20.06), pseudobulbs (2.73) and pseudo bulb girth $(1.94 \mathrm{~cm})$. Plant height was highest $(59.79 \mathrm{~cm})$ in a treatment with NPK 30:30:30 with Ca, Mg and Mn along with BA 25 ppm and $\mathrm{GA}_{3}$ 50 ppm. Treatment with NPK 20:20:20 with Ca, Mg and Mn along with BA 50 ppm and $\mathrm{GA}_{3} 100$ ppm gave maximum number of spikes / plant (2) (De, et al, 2013).

\subsubsection{Post-harvest Management}

\subsubsection{Harvest}

Dendrobium orchid spikes possess the vase life of 2 to 3 weeks. Usually, $40-60 \mathrm{~cm}$ long floral spikes with 10-15 flowers are harvested at a stage when all flowers are open except the top bud. Harvested sprays should be immediately placed in clean buckets of water with the cut ends submerged about 2-3 inches. Then the sprays are taken into the cool shaded packing area. In Dendrobium, it has been reported that flowers harvested early in the morning, generally last longer than those harvested in the late morning.

\subsubsection{Pre-cooling}

This is the fast removal of field heat and it is an important operation in post-harvest handling and transport of cut flowers, wherever flowers are held dry pack. All flowers should be pre-cooled immediately after harvest by placing them in cold storage without packing or in open boxes until they reach the desired temperature. These temperatures variy with species and cultivar: Cattleya $\left(7-10^{\circ} \mathrm{C}\right)$, Cymbidium and Paphiopedilum $\left(0.5\right.$ to $\left.4^{\circ} \mathrm{C}\right)$, Dendrobium $\left(5-7^{\circ} \mathrm{C}\right)$. Pre-cooling lowers respiration rate and decreases the breakdown of nutritional and other stored materials in the stems, leaves and petals; and delays bud opening and flower senescence. It also prevents rapid water loss and decreases flower sensitivity to ethylene. Several pre-cooling techniques such as room cooling, forced air cooling, hydro-cooling, vacuum cooling and ice bar cooling etc. are available. 


\subsubsection{Pulsing}

The absorption of chemical solutions containing sugars and germicides through the lower cut bases of flower stems is known as pulsing. Pulsing may be used by growers, wholesalers or retail florists in order to enhance the cut flowers subsequent vase life in water. Pulsing is employed with higher concentrations of sugar, mainly sucrose, the percentage of which varies with species and cultivars. Other chemicals used in the pulsing treatments are STS, $\mathrm{AgNO}_{3}, \mathrm{HQ}, \mathrm{MH}, \mathrm{AOA}, \mathrm{CaCl}_{2}, \mathrm{CoCl}_{2}$, nickel sulphate, aluminium sulphate and benzyladenine. Pulsing is found to be of great value in prolonging life, promoting opening and improving the colour and petal size of petals through osmo-regulation. In Dendrobium hybrid 'Pompadour'pulsing with 25 ppm $\mathrm{AgNO}_{3}+135$ $\mathrm{Na}_{2} \mathrm{~S}_{2} \mathrm{O}_{3}, 5 \mathrm{H}_{2} \mathrm{O}$ for 30 minutes increases vase life of cut flowers. In Dendrobium cv. 'Sonia' pulsing with $4 \%$ sucrose +400 ppm HQ recorded the highest vase life of 21.33 days.

\subsubsection{Bud Opening}

This is the procedure of harvesting flowers at a stage earlier than normally considered as the cutting stage and then opening the buds off the plant. Such types of post harvest handling may be applied by growers or wholesalers. Bud opening of flowers increases longevity of cut flowers by reducing the sensitivity of flowers to extreme temperatures, low humidity and ethylene, saving space during shipment and extending the useful storage life. The sugar concentration used is lower than the concentration of pulsing and the optimum temperature is kept lower. In the Dendrobium hybrid 'Thongchai Gold' opened flowers had 29\%, half opened flowers had $28.25 \%$ and buds had $16.17 \%$ reducing sugars. In Dendrobium hybrids, HQS or $\mathrm{AgNO}_{3}(50 \mathrm{ppm})$ is effective for opening of tight bud cut flowers. It has been reported that a preservative solution containing $225 \mathrm{ppm} \mathrm{HQS,} 30 \mathrm{ppm} \mathrm{AgNO}_{3}$ and 4\% glucose increased bud opening and the time to wilting of the open florets of Dendrobium Cv. 'Ceasar'. In the Dendrobium hybrid 'Thongchai Gold', the maximum percent of fully opened buds $(66 \%)$ was recorded with sucrose $(4 \%)+\mathrm{Ca}\left(\mathrm{NO}_{3}\right)_{2}(1 \%)$ followed by sucrose (4\%) + acetyl acetic acid (100 ppm) (60\%). Longest vase life (36 days) was found with sucrose $(4 \%)+\mathrm{Al}_{2}\left(\mathrm{SO}_{4}\right)_{3}(100 \mathrm{ppm})$ followed by sucrose $(4 \%)+$ acetyl acetic acid (100 ppm) (33 days).

\subsubsection{Preservatives}

Preservatives are used in the holding solutions in the form of tablets containing a mixture of chemicals such as sugars, germicides, salts, growth regulators etc. In addition, the chemicals are employed during conditioning, pulsing and for making bud opening solutions to improve flower shape, size and opening and colour of the flowers.

Sugar, biocide, anti-ethylene compounds and hydrated compounds are used for conditioning. The sugar and biocide solutions are effective for opening of bud cut flowers. 
The vase solution should contain sugars, an acidifying agent and a biocide. Citric acids are mainly used for acidifying agents and hydroxy quinoline as biocides. Metallic salts like silver nitrate, cobalt chloride, aluminium sulphate, zinc sulphate, calcium nitrate and nickel chloride have been found for prolonging post-harvest life of various cut flowers. A combination of biocide, sugar and hormone (8-HQC $100 \mathrm{ppm}+$ sucrose $2 \%+$ BA $25 \mathrm{ppm}$ ) remarkably enhances the post-harvest life of the Dendrobium cut flowers. New chemicals that have been found promising as floral preservatives are ethylene inhibitors like amino-oxyacetic acid, 1-amino cyclopropane, aminotriazole, aminoethoxy vinyl glycine, alpha aminoisobutyric acid, diazocyclopentadiene and phenidone. Holding solutions for increased longevity of Dendrobium as reported by various workers are 8-HQC (200 ppm) + sucrose (2\%), $0.5 \mathrm{mM} \mathrm{AOA}+4 \%$ sucrose, AgNO3 (30 ppm) + 4\% sucrose, 400 ppm HQ + 30ppm AgNO3 + 2\% sucrose, 200 ppm 8-HQS + 50ppm AgNO3 + 8\% sucrose (Bhattacharjee and De, 2005).

\subsubsection{Grading}

The export quality orchids are graded to maintain high standards of excellence. Sprays are graded according to length, colour, flower size etc. The grading is done in four standard sizes, based on the quality of the stalk and spike length for each grade (Tab. 9.5).

Tab. 9.5: Grading of Dendrobium cut flowers

\begin{tabular}{lll}
\hline Name of the grade & Length of the spike & No. of opened flowers \\
\hline SMALL-S & $30 \mathrm{~cm}$ & $4-5$ \\
MEDIUM-M & $40 \mathrm{~cm}$ & $6-8$ \\
LARGE-L & $45 \mathrm{~cm}$ & $8-10$ \\
EXTRA LARGE-XL & $50 \mathrm{~cm}$ & $>10$ \\
\hline
\end{tabular}

\subsubsection{Packaging}

The flower spikes of Dendrobiums are first packed in polyethylene sleeves of standard thickness. The standard is to bunch around 5 spikes of the same grade and variety in a pack box. Each stem in the box should be placed in a tube containing water or preservative solution. During shipment, loss of water could be supplemented by employing flower tubes or vials, which could be filled with water or preservative solution. Instead of small tubes, cotton wrapping can also be used, in this case cotton pieces should be dipped in water or preservative solution. Then a piece of polythene can be used to cover the cotton and it should be tied with rubber band. And cushioning materials should be provided in the back side of the sleeve to avoid damage during transportation. 
Graded flowers are then packed in suitable size of boxes. In order to check movement of spikes within the boxes during transit the base of the spikes should be tied to the base of the carton by adhesive tapes. Dendrobium flower spikes are normally packed in carton of different sizes. The length of the carton varies mainly based on the length of the flower spikes. The carton should be provided with sufficient numbers of holes or vents for aeration. The carton is exclusively designed to ensure flowers are better cared for and reach their destination in pristine conditions. In Dendrobium hybrid 'Sonia-17' a low gauge polyfilm of 100 gauge thickness the cotton dipped in 8-HQS (25 ppm) covering the base of the spike had maximum vase life and flower quality.

\subsubsection{Storage}

Storage of cut flower is an essential part of floriculture industry. Tropical orchids like Dendrobium, can be stored at $7-10^{\circ} \mathrm{C}$ and $90-95 \% \mathrm{RH}$. The longest vase life of 19 days has been observed in Dendrobium hybrid Sonia 28 followed by 15 days in Sonia 17 when stored at $10^{\circ} \mathrm{C}$. The orchids stored below optimum temperature cause chilling injury characterized by darkening of the labellum. In extreme cases, the sepals and petal also get affected. Orchids are sensitive to ethylene and the storage environment should be free from ethylene which can be effectively accomplished by proper ventilation and placing ethylene scrubbers or absorbent containing potassium permanganate in the area.

\subsubsection{Value addition}

Value addition in flower crops can directly or indirectly influence the floral market to a great extent. Value addition in flower crops by employing techniques like colouring in white flowers, flower dehydration, flower processing, advances in flower arrangements etc. can add value up to 5 to 10 times

\subsubsection{Tinting}

This is one of the most important value addition techniques for imparting desired shades of colour to the flowers. It is a very useful technique in flower crops where pigments are absent or light and dull. Aesthetic beauty of the cut flowers and dry flowers were enhanced through tinting. Translocation, immersion and spraying are methods followed in tinting. Stopping irrigation two days before the harvest of flower improves the flower colour. It can be combined with pulsing solution. Edible dyes of 0.25 to $1 \%$ can be used along with pulsing solutions for 30 minutes to 3 hours. Different dyes and strains such as food colours, feulgen stain, bromocresol blue, bromocresol green, eosin yellow, ammonium purpurate and phenol red at varying concentrations can be used to get flowers with different shades of colours. Artificial colouring can be done 
by using edible dyes like Apple green, Kalakhatta, rose pink etc. Employing this technique, white flowers can be used to result in all shades of red, blue, green and yellow.

\subsubsection{Preparation of Bouquet}

Bouquets are prepared with different colours of Dendrobium cut flowers selected and combined according to colour and arranged with some foliage plants and packed in boxes.

\subsection{Phalaenopsis (Orchidaceae)}

\subsubsection{Introduction}

Phalaenopsis is also known as 'Moth Orchid' because when the amabilis species was first observed in its natural habitat, the long inflorescences of pendulous white flowers that festooned the jungle tree tops were thought to be clusters of moths. This orchid originated in the jungles of South and Southeast Asia, Indonesia, Malayasia and the Philippines.

\subsubsection{Botanical Description}

Phalaenopsis consists of 70 species of monopodial orchids ('Moth Orchids')distributed in Asia, the Philippines, Indonesia, Malayasia, Australia and New Guinea. The plants are pseudobulbless with short stems covered by clasping leaves. The leaves are leathery, and thick. The inflorescence arises from the axil of leaves, drooping or erect bearing spikes of $100 \mathrm{~cm}$ length. The flowers are spectacular, long lasting and white, pink, yellow or mottled. There are two types of Phalaenopsis . In the first type, leaves are thick and fleshy, elongate-elliptic and obtuse in apex. The flowers petals are broader than the sepals and the lip possesses two attractive centre lobes and appendages. The flowering stem is up to $60 \mathrm{~cm}$ long and bears 15 or more blooms. Species belonging this group are Phalaenopsis parishi, P. aphrodite, $P$. stuartiana, $P$. schilleriana and $P$. sanderiana. In the second type, plants are short stemmed bearing fewer blooms. The flowers are smaller with equal sizes of sepals and petals and without any appendages. Species belonging this group are Phalaenopsis cormi-cervi, P. leuddemanniana, P. equestris and P. mannii. 


\subsubsection{Importance and Uses}

Phalaenopsis are commonly used as pot plants and cut flowers and are suitable in hotel arrangements, hanging arrangements, households, boutique stores, weddings, funerals, birthdays, etc. The purity and brightness of the Phalaenopsis make it especially appealling for weddings and corsages.

\subsubsection{Hybrids (De, 2014)}

Tab. 9.6: Common commercial Phalaenopsis hybrids

\begin{tabular}{|c|c|c|}
\hline Colour & Name & Remarks \\
\hline White & $\begin{array}{l}\text { Taisuco Crane, Taisuco Kochdian, Cygnus, Yukimai, } \\
\text { Sogo Musadian, White Dream, Florida Snow }\end{array}$ & Large flowered \\
\hline Pink & $\begin{array}{l}\text { Nobby’s Pink Lady, Minho Valentine, Minho King } \\
\text { Beauty, New Cinderella, Taisuco Firebird, Sogo Smith }\end{array}$ & Large flowered \\
\hline Striped hybrids & Sogo Zebra, Chih Shang Stripes, Okay Seven & \\
\hline Spotted hybrids & $\begin{array}{l}\text { Carmela spots, Rousserole, Soroa Delight, Leopard } \\
\text { Prince }\end{array}$ & Pretty \\
\hline Yellow & $\begin{array}{l}\text { Carol Campbell, Emil Giles, Brother Lawrence, Taipei } \\
\text { Gold, Golden Bells, Sogo Managers, Brother Passat }\end{array}$ & 5-10 flowered \\
\hline $\begin{array}{l}\text { Spotted \& Barred } \\
\text { yellow }\end{array}$ & $\begin{array}{l}\text { Golden Amboin, Yellow Queen, Ching Her Buddha, } \\
\text { Golden Sun }\end{array}$ & \\
\hline $\begin{array}{l}\text { Orange red to deep } \\
\text { lavender }\end{array}$ & $\begin{array}{l}\text { Cordova, Lonnie Morris, Sogo Pony, Sogo Rose, Sogo } \\
\text { Grape }\end{array}$ & \\
\hline $\begin{array}{l}\text { Red spots on yellow } \\
\text { or cream coloured } \\
\text { background }\end{array}$ & Brother Purple, Sogo Prince, Golden Peoker & \\
\hline Colour blending & $\begin{array}{l}\text { Sweet Memory, Zuma Aussie Delight, Pago Pago, } \\
\text { Brother Sara Gold }\end{array}$ & \\
\hline $\begin{array}{l}\text { White or Yellow base } \\
\text { colour with black } \\
\text { blotches }\end{array}$ & $\begin{array}{l}\text { Ever Spring Light, Yu Pin Pearl, Yu Pin Panda, Bright } \\
\text { Peacock }\end{array}$ & Mutants of Taiwan \\
\hline Multiflora hybrids & $\begin{array}{l}\text { Be Glad, Cassandra, Vilind, Carmelas Pixie, Zuma's } \\
\text { Pixie, Timothy Christopher, Be Tris, Quevedo }\end{array}$ & Bred at California \\
\hline Miniature hybrids & Micro Nova, Mini Mark, Anna-Larati Soekardi & $\begin{array}{l}\text { Require lower day } \\
\text { and night temper- } \\
\text { ature and lower } \\
\text { humidity }\end{array}$ \\
\hline
\end{tabular}




\subsubsection{Bigeneric Hybrids}

Aeridopsis $=$ Phalaenopsis $x$ Aerides

Arachnopsis $=$ Phalaenopsis $x$ Arachnis

Doritaenopsis $=$ Phalaenopsis $x$ Doritis

Phalanetia $=$ Phalaenopsis $x$ Neofinetia

Renanthropsis $=$ Phalaenopsis $x$ RenantheraVandaenopsis $=$ Phalaenopsis $x$ Vanda

\subsubsection{Trigeneric Hybrids}

Sappanara $=$ Phalaenopsis $x$ Arachnis $x$ Renanthera

Trevorara $=$ Phalaenopsis $x$ Arachnis $x$ Vanda

Lycockara $=$ Phalaenopsis $x$ Arachnis $x$ Vandopsis

Rhyndoropsis = Phalaenopsis $x$ Doritis $x$ Rhyncostylis

Moirara $=$ Phalaenopsis $x$ Renanthera $x$ Vanda

Yapara $=$ Phalaenopsis $x$ Rhyncostylis $x$ Vanda

\subsubsection{Tetrageneric Hybrids}

Bogardora $=$ Ascocentrum $\times$ Phalaenopsis $x$ Vanda $x$ Vandopsis

Bokchoonara $=$ Arachnis $x$ Ascocentrum $x$ Phalaenopsis $x$ Vanda

Edeara $=$ Arachnis $x$ Phalaenopsis $x$ Renanthera $x$ Vandopsis

\subsubsection{Pentageneric Hybrids}

Sutingara $=$ Arachnis $\times$ Ascocentrum $\times$ Phalaenopsis $x$ Vanda $\times$ Vandopsis Macekara $=$ Arachnis $x$ Phalaenopsis $x$ Renanthera $x$ Vanda $x$ Vandopsis

Paulara $=$ Ascocentrum $\times$ Doritis $x$ Phalaenopsis $x$ Renanthera $\times$ Vanda

\subsubsection{Natural Hybrids}

Phal. Amphitrita, Phal. intermedia, Phal. leucorrhoda, Phal. rothschildiana, Phal. Singulifera

\subsubsection{Inter-specific Hybrids}

'Borneo Belle’, 'Cecile’, 'Fuscabell', 'Anna', 'T.H. Pearl', 'renchy’s Plastic Yellow', 'Herman Sweet', ‘Gold Veins', 'Amabell’, ‘Algicora', 'Smiling Tiger’.

\subsubsection{Inter-varietal Hybrids}

'Free Gold', 'Durga Ko Dil', 'Popp Queen', 'Red Hot Girl', 'White Ghost', ‘White Galaxy', 'Dotted Perfection', 'Hamana Gold’, ‘Triastar Diamond', ‘Tiraster Golden Lip', 'Archie 
Goodwin’, ‘Taida Sun Smile’, ‘Pink Pixie’, ‘Exotics Plum Red’, ‘Woodson’s Dalmation', 'Walnut Valley Peachy'.

\subsubsection{Variety-species Hybrids}

'Hemlata and Chris', 'Hama Snow', 'Berry Blossoms', 'Good Time Charlie', 'Stone Trail', 'Taisuco Imperator', 'Taisuco Sumatra', 'Thirty Eight Special'.

\subsubsection{Climatic Requirements}

\subsubsection{Light}

Phalaenopsis orchids are not like Cymbidium, Cattleya, regarding their light needs, and do well in indirect light. For this reason, healthy Phalaenopsis can be grown indoors in windowsills, sun rooms, and shaded greenhouses and under artificial lights in most temperate climates. The requirement of light is 1000-1500 foot candles for winter and 800-1200 foot candles in summer. Phalaenopsis can be grown under artificial light. Phalaenopsis can be grown 9-12 inches under fluorescent lights or 4 to 6 feet under 400 watts high intensity discharge lights or high pressure sodium lights. If Phalaenopsis does not have a flower spike growing by February, move it where it will receive more light. The indication that the correct amount of light has been received is that the foliage will appear yellow-green, not dark green. Dark green leaves or the new leaf growing longer and narrower than the old leaf indicates the light is too low. Too much light causes white, dried, burned areas on the leaf, and will have short flower spike. Inadequate light results in succulent, floppy, dark green foliage with no flowers. In cloudy winter conditions artificial light should be supplemented, whereas direct sunlight will damages the plant, therefore placing the plant near a bright window is good. In green houses, 750-1500 foot candle light is judicious. If grown indoors, Phalaenopsis should be placed in a North East window to avoid hot and direct sun. Higher intensity light is recommended for boosting growth the vegetative stage, particularly for growing leaves and roots and flower induction. At flowering, Phalaenopsis can tolerate low light intensity (100 foot candle).

\subsubsection{Temperature}

The Phalaenopsis is a tropical plant, and consequently temperatures lower than $15^{\circ} \mathrm{C}$ and above $32^{\circ} \mathrm{C}$ should be avoided. For an appropriate growth endeavors should be made to maintain an average temperature of $26-27^{\circ} \mathrm{C}$ during the growing phase and $19-21^{\circ} \mathrm{C}$ during the phase of flowering. During winter the temperature should be maintained between 18 to $20^{\circ} \mathrm{C}$. A temperature of $18^{\circ} \mathrm{C}$ is particularly necessary in the event that the induction of buds needs to be enhanced in conditions of inadequate light or high daytime temperatures. Care should be taken to ensure a minimum night time temperature of $15^{\circ} \mathrm{C}-20^{\circ} \mathrm{C}$ 
for the rest of winter. Although they are warm growers, above $30^{\circ} \mathrm{C}$, they tend to stop growing, so if this is likely take steps to reduce the temperature by improving ventilation or misting the floor etc. Continued periods of exposure to low temperature below $10^{\circ} \mathrm{C}$ or a rapid drop in temperature can cause chilling injury which ultimately results in poor growth and yellow sunken spots on the leaves. Higher temperature coupled with higher humidity will not affect the plant. Phalaenopsis can tolerate higher temperature $\left(30^{\circ} \mathrm{C}\right.$ to $35^{\circ} \mathrm{C}$ ) for a few hours if sufficient water is in pot. They need cool temperature for a month at the time of bud development. Higher temperature delays the flowering and aborts the bud at $28^{\circ} \mathrm{C}$ and more during flower bud development.

\subsubsection{Humidity}

Phalaenopsis can perform better with the humidity of 50\% or higher. At sufficient humidity plants grow lushly and leave looks healthy. Insufficient humidity cause stunting of plant, accelerated premature falling of buds, dehydrated and shriveled leaves and papery texture of flower edges. In greenhouses, the humidity can be easily controlled by watering the foot path and benches or by humidifier. Humidity can be improved sufficiently in the growing area. Keeping of water in plastic tray below the benches is a good option to maintain the humidity in green house. Misting can also be done to increase humidity for a limited period, but it causes leaf spot diseases if there is not good air circulation. To increase the humidity level, companion plants like ferns, bromeliads, and other foliage plants can be placed near the Phalaenopsis plant in the house.

\subsubsection{Ventilation and Air Circulation}

It is necessary to provide enough space between plants and to allow air movement (slight breeze) to help dry the leaves. Using an electric fan to induce air movement inside the greenhouse is common. Plants should not be left in stagnant air, as they can become infected by bacteria and fungus spores. Fans should be used constantly to reduce temperature on hot days and to dry plants out for cold nights. In most of the areas where Phalaenopsis are found, gentle air blows. Air movement in growing environment ensures good growth and less infestation of diseases and pests. Ceiling and oscillating fans are effective for providing gentle air flow in hobby greenhouses or indoor growing areas. Both can cover large areas with a constantly changing air flow pattern without excessively drying the plants.

\subsubsection{Growth and Flowering}

The Phalaenopsis passes through two distinctive phases i.e. vegetative and flowering for production. Plants are grown in separate greenhouses with required temperatures during these two phases. 


\subsubsection{Vegetative Phase}

The vegetative phase begins when plants are removed from tissue culture flasks and are transplanted into community trays. Forty to fifty plants from a flask can be accommodated into 1300 to $1500 \mathrm{~cm}^{2}$ square or rectangular trays or in 128-cell plug tray. The vegetative phase is again divided in three phases. The first phase comprises pricking out from flask (25-30 weeks), while the second phase includes repotting to an intermediate pot (27-32 week) and the third phase is to planting in a bigger pot (10-12 week). During vegetative phase, the plants must be grown at $28^{\circ} \mathrm{C}$ or higher to avoid immature inflorescences. The higher temperature will promote rapid growth of leaves. Phalaenopsis can tolerate temperatures as high as $32^{\circ} \mathrm{C}$, to $35^{\circ} \mathrm{C}$ for a few hours per day subject to sufficient moisture in the substrate and good aeration. In general, about 50 weeks are required to complete these phases. During the initial stage of growth, during the first 4 to 8 weeks after transplanting the recommended maximum light intensity is $75 \mu \mathrm{mol} . \mathrm{m}^{-2} \mathrm{~s}^{-1}$ to acclimatize the plants to the greenhouse. A maximum of $300 \mu \mathrm{mol} . \mathrm{m}^{-2} \mathrm{~s}^{-1}$ light intensity is maintained during the growth phase.

\subsubsection{Flowering Phase}

Phalaenopsis plants already developed 4 to 5 large leaves, can be exposed to cooler temperatures to induce the flowering process. Flower induction occurs when exposed to less than $26^{\circ} \mathrm{C}$ temperature during the day. Generally, growers maintain a $25^{\circ} \mathrm{C} / 20^{\circ} \mathrm{C}$ day/night temperature regime for flower spike initiation. However, plants exposed to a constant $25^{\circ} \mathrm{C}$ temperature, produce spikes at a faster rate than those exposed to $26^{\circ} \mathrm{C}$. After being exposed to this temperature for a period of 4 to 5 week, plants can be grown at $17^{\circ} \mathrm{C}$ to $26^{\circ} \mathrm{C}$ to time the flowering at specific date. Inflorescence and flower bud number are higher when Phalaenopsis is induced at 14 to $17^{\circ} \mathrm{C}$ compared to warmer temperatures. In warmer regions, the flowering can be regulated in air conditioned green houses for year round production.

At a favorable environmental condition $\left(28^{\circ} \mathrm{C}\right)$ bud initiation occurs after the spikes attain $5 \mathrm{~cm}$ in length. However, if a plant with a young inflorescence (less than $10 \mathrm{~cm}$ ) is subsequently grown at $28^{\circ} \mathrm{C}$ or higher spike can form 'keiki' instead of flower buds' or buds may abort. During the flowering phase, higher temperatures may increase spike but number and size of flower may decrease. If the light intensity is excessively low during flowering phase, flowering can be inhibited.

\subsubsection{Propagation}

\subsubsection{Division/ Cuttings}

This type of propagation can be done by using two types of techniques. Phalaenopsis can be propagated asexually by keikis forming on old flower stalks or on the sides of the main stem. Top cutting can be practiced on long drooping plants, after which, 
new plants will shoot from the remaining stem. Using lanolin paste with Benzyl adenine (BA) on buds in flower stalks to induce kiekies has given successful results. Kiekies can be planted in clay or plastic pots with chopped charcoal and coconut husk. Stem propagation sometimes also involves the application of keiki paste or a similar product to dormant nodes of the flower spike, an ideal method for non-commercial growers. When the keikis have 2-3 roots, it can be removed, by slicing between the stem and the keikis, or cutting the stem above and below keikis attachment point. The new plant can now be potted up and grown on. If more flowers are desired, cut the stem as above, but do not move the plant.

The Phalaenopsis mother plant is topped and it continues to grow vertically and discard its lower leaves that had served as a storage vessel of water and nutrients. New roots are produced above the leafless stem, as the plants continue growing vertically. The stem can be cut below the new roots. The top part, with leaves and roots, is repotted after proper care of the cut. The remaining stub can be left for a few days/ weeks. Soon, new little plants will be found growing out of the old stub. These keikis can be repotted in the media.

\subsubsection{Tissue Culture}

Phalaenopsis can be propagated by tissue culture technique using shoot tip, nodal flower-stalk, internodal section, leaf tip and root tip in Vacin and Went medium, Murashige-Skoog medium, REM, Knops Solution, Hyponex/Kyoto medium New Dogashima medium.

\subsubsection{Cultivation}

\subsubsection{Plant Material}

The plants are generally available in flasks containing 20 to 25 plants or in nursery trays containing 40-50 plants. As soon as they are received, it is necessary to acclimatize the plants for a few weeks to the local growing. The plants in nursery trays are better as there is less mortality and a reduction of cultivation period by approximately 5-7 month.

\subsubsection{Potting}

The mature plant with 2 to 3 leaves and healthy roots is generally shifted to a nursery tray from the flask. Once they harden and the leaf attains a span of 10-15 cm size in the nursery tray, they can be shifted to pots. The plants need to be sorted out in two grades i.e. bigger and smaller plants, before planting. Small plants often require 3-4 months more before they are shifted to pots than bigger plant. Smaller plants can be kept together in community pot. Seedlings can be planted $1 \mathrm{~cm}$ apart. 
The potting material should be damped and should be packed firmly and it is required to water the seedling gently and thoroughly. The community pot needs to be covered with plastic and left slightly open. This will provide the seedlings with a humid environment and need to keep the plant in partial shade. In few months the seedlings will be ready for transplanting as like bigger plant.

\subsubsection{Containers}

The most common pot or container is a plastic or clay pot. In general, the orchid pot should have a greater number of holes and larger size, both at in the bottom and sides for better drainage. Phalaenopsis pots are shorter and shallow $(10 \mathrm{~cm})$ or have a larger diameter with a broader base for more stability. Most of the growers prefer plastic pots over clay pots because they are inexpensive, durable, have a lower accumulation rate of salts and are easy to clean. In Phalaenopsis, a healthy and more roots can be obtained in transparent pots as compared to dark coloured pots. Generally, white colored transparent pots of 12 to $20 \mathrm{~cm}$ sizes are preferred for Phalaenopsis.

\subsubsection{Potting Media}

Potting material must support the plant, drain out rapidly, retain moisture and should have durability. Phalaenopsis cannot withstand long dry spells because they do not have any water storage organs. A good potting mix contains coconut husk pieces, charcoal or broken pieces of roofing tile with coconut peat. $25-30 \%$ of the media should be charcoal or tile pieces to ensure adequate drainage. Phalaenopsis can be potted on clay or plastic pots, with charcoal and coconut husks, or mounted in wooden slabs. Currently, the use of tree fern roots is being discouraged for the conservation of our endangered giant tree ferns. Pre-soaked coconut husk is another good medium for Phalaenopsis. Another alternative medium is a 1:1 mixture of sand and coconut choir dust. For immature or miniature Phalaenopsis a fine mix consist of 3 parts coco-peat, 1 part fine charcoal and 1 part perlite and 1 part sphagnum moss is filled in $10 \mathrm{~cm}$ size pot. However, for standard size plant the growing media consist of 4 part coconut husk, 1 part medium charcoal, 1 part medium size perlite and 1 part medium sphagnum moss.

\subsubsection{Repotting}

Repotting should be done if there is wilting of foliage, the plant is loose in the pot, flowers do not last long, there are brown tips on the leaves etc. The plants prefer good aeration around the roots and this is the easiest way to check the condition of the root system. The Phalaenopsis are best repotted after flowering in the late spring or early summer. Repotting is done about once a year in an appropriate sized pot. During repotting, it is required to cut or break the base of the stem is carefully. Except main also other roots should be cut off and soak the plants and roots in a standard Mancozeb solution for 10 minutes then 
seal the bottom of the stem with a thick paste of Mancozeb or Thiram. Plants should be air dried before repotting. Growing media is the same as initial potting media.

\subsubsection{Watering}

Water needs are influenced by humidity, potting media, type of pot, size of pot, time of year and the orchid. Over watering is the biggest killer of orchids. Phalaenopsis do not like water as do most other types of orchid. The pot should not be watered until very nearly dry. Phalaenopsis do not prefer frequent watering, although younger plants require more watering than matured plants. This can be accomplished by misting the plants instead of water sprinkling. Watering is necessary twice per day during very hot and dry months, and only 2-3 times per week during wet months or none at all for matured plants. The quality of water is an important factor for governing the growth and flowering. Water must be free from chemical and visible contamination. Water for Phalaenopsis should not contain excessive harmful elements like sodium, chlorine and bicarbonate. In the absence of good quality of water, deionised water can be used as substitute. However, rainwater is best for all orchids.

\subsubsection{Fertilizers:}

Phalaenopsis plants need nutrition twice or once a week. Seedlings could be sprayed with very dilute fertilizer every day after watering. Plants need to be watered heavily once a week to flush excess salts and should be moist before applying of fertilizers. Use of balanced foliar fertilizer with trace elements is always beneficial for orchids. Weak fertilizer applied frequently is better than strong application.

Reduction of fertilizers is suggested once flower spikes form and under low light conditions. It is important to note that feeding depends upon some other environmental factors: the higher the light the more food is required and the more food is available at the roots, the more of water is necessary to prevent salt damage to the roots. When plants are grown under lower light and temperature, less water and nutrition is required. The $\mathrm{pH}$ of fertilizer solution needs to be maintained between 5.2 and 6.2. The EC of the nutrient solution should lie within the range of 0.8 and $1.2 \mathrm{mS} / \mathrm{cm}$. Slow release fertilizers like Nutricote (13:13:13) or Osmocote (13:13:13) can be used at a level of 1 table spoon/plant while planting. The most common form of fertilizer used with Phalaenopsis is the water soluble type. The water soluble is a 19:19:19 or 20:20:20 NPK with micronutrients which are available in market and users friendly. Generally, $1 \mathrm{~g} / \mathrm{l}$ at weekly intervals is sufficient for growth. It is better to fertilize the plant frequently with diluted rate. The excess rate or higher concentrations will damage the plant. At the active growth stage the Phalaenopsis require more nutrition than in winter or inactive phase. In the dormant period, the fertilizers should be applied at lesser rate $(50 \%)$. If salt accumulation occurred, it needs to clean with flushing of water. 


\subsubsection{Flower Production}

Mature plant with 5 fully developed expanded leaves may be induced to flower. Generally, flower production starts 8 months after planting subject to proper management. It is important that plant should be healthy, large enough and the pots have a good root system to bear the flowering. Phalaenopsis will naturally induce spike when it is fully grown. Flower production can be manipulated by controlling light and temperature regimes. The spikes become ready to harvest when the spike has approximately three unopened buds. New and heavier branches could develop from the plant base after harvesting. The development of this new branch will take more time than the development of a branch from a bud. There should be at least 12 plants/ sq.m and the complete growing period approximately 5 years. On average, the plant produces 2 branches / plant/year.

\subsection{Premature Flowering}

Sometimes flower spikes develop before the plant matures. The premature flowers will need to be removed to boost vegetative growth. At the early stage, the flower inflorescence, or stick, is soft enough and can be pinched off easily. During the growth phase, the maintenance of temperature at $27^{\circ} \mathrm{C}$ limits the premature flowering.

\subsubsection{Training of Spike}

Phalaenopsis is a marketable flower and consumers prefer straight flower spikes with better presentable form. The Phalaenopsis flower stems are supported with sticks made of plastic, bamboo or metal at the time when flower buds begin to swell. Tying of spike should be secure and firm with the stake. Use of twist tie, soft cotton string, small green cable ties and loop tape are better than wire, which could damage the stem. The first tie has to be placed on the lower part of the spike close to the first node. Another tie should be placed a few inches higher on the flower spike. If necessary, more ties can be placed at suitable distance. The spikes are attached to overhead wires with the help of strings to avoid bending. The flower sprays are supported with a small hook from the strings when the lower bud starts swelling.

\subsubsection{Harvest and Yield}

The 40-60 cm long spikes containing at least 8-10 flowers are harvested when all flowers are fully open. Average flower production is 6 to 7 stems / plant /year.

\subsubsection{Post-harvest Management}

\subsubsection{Vase life}

Normally, Phalaenopsis cut flowers last for 15 to 21 days. 


\subsubsection{Pulsing}

Chemicals like Chrysal are added to water to enhance vase life. In Phalaenopsis, pulsing with $0.5 \mathrm{mM}$ STS for 24 hours blocks the deleterious effect of ethylene.

\subsubsection{Storage}

The harvested flowers need to be kept at proper temperatures. In general, Phalaenopsis flowers can be stored at 7 to $10^{\circ} \mathrm{C}$ for two weeks. The low temperature helps to slow down respiration and depletion of reserved food materials of petals.

\subsubsection{Packaging}

The Phalaenopsis, cut flower are packed in single window gift boxes of $100 \mathrm{~cm}$ x $15 \mathrm{~cm}$ x $11.5 \mathrm{~cm} .25$ to 30 flowering stems are packed in a box depending on the number of flowers/ stem. During packing of flowers, boxes are cooled at $20^{\circ} \mathrm{C}$. Pre-cooled boxes are more efficient than packing a box and then placing in a cooler place, a process that requires hours to bring flowers to the optimum temperature range. Cut stems are kept in cooler places prior to packing. It is best to pack in cooled rooms to reduce respiration and condensation build-up in the slips.

\subsection{Cattleya (Orchidaceae)}

\subsubsection{Introduction}

Cattleyas are considered by most people to be fascinating home garden orchids. Flowers are long lasting and possess a beautiful fragrance. Cattleya hybrids also produce the biggest orchid flowers. Named in the honour of William Cattley, a noted $19^{\text {th }}$ century English Horticulturist, this genus falls into subtribe Laeliinae, which comprises many Cattleya like species. Of the many intergeneric hybrids, Laelia, Sophrinitis and Brassovola are the main genera used in hybridization programs. Cattleya orchids are also known as the 'Queen of Orchids'.

\subsubsection{Botanical Description}

Cattleya consists of 113 species from tropical America. The plants possess elongated pseudobulbs and may be unifoliate or bi-foliate. The leaves are thick and leathery. The present day hybrid cattleyas belong to the unifoliate group. The flowers are 5 to $15 \mathrm{~cm}$ in size and they occur in all colours, except true blue and black.

Unifoliate cattleyas bear up to 5 flowers per inflorescence whereas bifoliate possesses 2 to 25 flowers per inflorescence. They are from the tropical Americas, but 
can also be found in the West Indies and Mexico. Cattleya orchids are epiphytes and have well-developed water-storage organs (called pseudobulbs) and large, fleshy roots. Cattleya orchid plants are long-lived perennials and will usually flower annually. These orchid plants are naturally erect, without need of much staking, and of a medium olive-green color.

\subsubsection{Importance and Uses}

In addition to cut flowers and pot plants, Cattleya orchids are ideal components for flower decorations including bouquets and flower arrangements. In addition, this orchid is used for making clay flowers.

\subsubsection{Hybrids (De, 2014)}

\subsubsection{Parents for Large Blue Cattleya Hybrids}

Cattleya warneri var. coerulea, Cattleya labiata var. coerulea, Cattleya mossiae 'Reineckiana Blue Lip', Cattleya gaskelliana ‘ Blue Dragon', Cattleya trianae ‘Blue Bird'

\subsubsection{Bigeneric Hybrids}

Brassocattleya $=$ Cattleya $\times$ Brassolvola

Epicattleya = Cattleya $x$ Epidendrum

Laeliocattleya = Cattleya $x$ Laelia

\subsubsection{Trigeneric Hybrids}

Vaughnara $=$ Cattleya $\times$ Brassovola $\times$ Epidendrum

Brassolaeliocattleya = Cattleya $x$ Brassovola $x$ Laelia

Rolfeara $=$ Cattley $\times$ Brassovola $\times$ Sophronitis

Osmentara = Cattleya $\times$ Broughtonia $\times$ Laeliopsis

Dialaeliocattleya $=$ Cattleya $\times$ Diacrinum $\times$ Laelia

Epilaeliocattleya = Cattley $\mathrm{x}$ Epidendrum $\times$ Laelia

Sophrolaeliocattleya $=$ Cattleya $\times$ Laelia $\times$ Sophronitis

\subsubsection{Tetrageneric Hybrids}

Iwanagara $=$ Cattleya $\times$ Brassovola $\times$ Diacrinum $\times$ Laelia

Yamadara $=$ Cattleya $\times$ Brassovola $\times$ Laelia $\times$ Epidendrum

Potinara $=$ Cattley $\times$ Brassovola $\times$ Laelia $\times$ Sophronitis

Kirchara $=$ Cattleya $\times$ Epidendrum $\times$ Laelia $\times$ Sophronitis 


\subsubsection{Intervarietal Hybrids}

'Day Tripper', 'Spring Break', 'Beau’s Apricot Gem', 'Dendis Angel', 'Dendis Bee', 'Sweet Peggy', 'Redland Icicle', 'Moonlight Glitter', 'French Cream', 'Mackay Drop', 'Nobiles Virgin', 'Summer Bouquet', 'Tokyo Life', 'Poo Hoon', 'Montking’, 'Black Wonder', 'July Sun', 'Pink Jaguar', 'Memoria Madan Tamang'.

\subsubsection{Inter- specific Hybrids}

'Eva's Fabula Andena', 'Oleo Stella' 'Oro Verde Azul', 'Mareeba Freckles', 'Brazilian Jewel', ‘Bird Flap', ‘Bucks Fizz', ‘Genes Dream', 'Little Lars', ‘Comwhite’, 'Amazon Blue’, 'Mini Green', ‘Jungle Nobility’, Berlin Moon', ‘Brazilian Ruby’, Brazilian Fire', ‘Brazilian Star'.

\subsubsection{Variety Species Hybrids}

'Maryglossa', 'Betty Blue', 'Koko Drop', 'My Partner', 'Pradit Spot', 'Summer Poole', 'Angaur' 'Baby Tata', 'Little Bells', 'Balkis Gem', 'Snow Field', 'Summer Pink', 'Berlin Star', 'Berlin Beauty’, ‘Memoria Bishnu Subba', 'Memoria Naren Rai', 'Leopard', 'Snow Tiger’.

\subsubsection{Blue Cattleya Hybrids}

Cattleya Alcmeda, Cattleya Bobby Howarth, Cattleya Intertexa, Cattleya Mrs. Myra Peters, Cattleya Veriflora

\subsubsection{Cultivation}

Cattleya orchids belong to a group of orchids which is the most colorful of all orchid species. Due to their relative ease of culture and adaptability, Cattleya orchids are among the most popular orchid genus grown because of their cross compatibility many genera, which have similar structures and a range of interesting and unique characteristics. Additionally, the Cattleya orchids belong to both the intermediate and warm climate groups of orchids under cultivation. Cattleya orchids lend themselves to many different types of cultivation and they will grow outdoors in trees in tropical landscaped gardens as well as in pots in shade houses and climate controlled green houses. Cattleya orchids are usually slow growers and can take up to three or even four years to flower. However, once they start flowering they will continue to do so all year round under their optimum growth conditions.

\subsubsection{Temperature}

The ideal temperature range of Cattleya orchid species is between 15 and $30^{\circ} \mathrm{C}$. Depending upon the temperature, Cattleya orchids should be watered about once or 
twice a week. In winter, the Cattleya orchid plants become stressed if the temperature drops below $15^{\circ} \mathrm{C}$. It is also essential to keep the orchid plant a little drier under those conditions because extended exposure to cold and damp simultaneously will result in rot. The Cattleya orchid goes into a state of dormancy and will wake up when the weather warms up again. Do not feed or water the Cattleya orchid plant when it is in a state of dormancy damage. During the summer, the Cattleya orchid plants should be watered and fed. Cattleya orchids should always be protected against frost in the cold winters.

\subsubsection{Light}

Cattleya orchids need medium to bright light with 2000 to 3000 foot candles. They thrive well under a 40\% shade cloth. Dark green but limp foliage indicates that they received little light. The Cattleya and its allied inter-generic hybrid orchids are capable of withstanding higher light, but they may become stressed if exposed for too long.

\subsubsection{Water and Humidity}

Cattleya orchids should be watered about once or twice a week, and more frequently during the hotter months of the year. Cattleya orchids may be allowed to dry out between applications of water. It is advised to always water the Cattleya orchids early in the day, so that the foliage will be dry by nightfall. They require 40-60\% relative humidity. During the summer months, it is necessary to feed and water Cattleya orchids to plump up the pseudobulbs and thus provide nutrients for storage purposes to be used during the winter rest period.

\subsubsection{Feeding}

Cattleya orchids are known as heavy feeders. This is especially true during their active growth period in spring. A high nitrogenous orchid fertilizer must be applied on a regular basis during spring. Application of dilute 20:10:10 (N:P:K) weekly fertilizer produces more flowers. Furthermore, well-rooted plants should be given regular feeds of nitrogen-based fertilizers. During summer, the fertilizer type may be changed to a good quality bloom booster that will harden the plant off and make it ready for flowering.

\subsubsection{Potting Mix and Repotting}

All Cattleya orchids, including all hybrid and orchid species that have been hybridized from the Cattleya orchid require a very open, friable potting mix and a very free draining compost containing at least 50 percent bark. They should be potted in a porous, free-draining medium. The most commonly used potting mixes are bark, shredded tree-fern fibre, various types of rock like granite chips, processed coconut fiber and lately, mixes based on peat moss and perlite and also osmunda. 
Cattleya orchids should be potted on an annual basis when the orchid plant is young or in its active growth period. Once the orchid plant has matured and begun to flower, repotting may occur every alternate year. Repotting of Cattleya orchids is best practiced soon after flowering, just when the new growth appears at the base of the pseudobulbs, and just before any new roots may have begun.

\subsubsection{Pests and Diseases}

All excess humidity increases the risks of fungus and bacterial infections. This can further result in a loss of new growth and in severe cases causes even permanent spotting on the leaves.

The ant is a serious pest to Cattleya orchids. They relish the sugary substance that is produced by the new flowers. They are carriers of scale insects. To prevent this, a grower should remove old bracts and sheaths and groom the orchid plants regularly.

Virus infection on Cattleya orchids are usually manifested as white striations in the flowers. This phenomenon is referred to as color-break. This color-break soon develops further into a brown streak. Viral infections on Cattleya orchids can be controlled effectively by making use of clean secateurs, blades, etc.

\subsubsection{Post-harvest Management}

\subsubsection{Stage of Harvest}

Spikes are harvested with fully open flowers. There may be one or more flowers on a spike of $25-40 \mathrm{~cm}$ length depending on the type.

\subsubsection{Storage}

Cut flowers can be kept at $7-10^{\circ} \mathrm{C}$ for 14 days in dry storage and 10 to $13^{\circ} \mathrm{C}$ in wet storage.

\subsubsection{Vase life}

Cut flowers last for 10 to 15 days in normal water.

\subsubsection{Preservatives}

STS $1 \mathrm{mM}+$ sucrose 1 percent. 


\subsection{Oncidium (Orchidaceae)}

\subsubsection{Introduction}

Oncidium species, their hybrids and inter-generic hybrids are suited to intermediate and warmer climates. The plants are epiphytic using hosts such as cactus plant and trees for support. Hybridization of Oncidium orchids with Brassia orchids, Miltonia orchids and Odontoglossum orchids results in an Oncidium orchid that has some warmth tolerance and beautiful flowers. Hybrids and some commercial species are used for cut flowers, hanging baskets and potted plants.

\subsubsection{Botanical Description}

Oncidium consists of 750 species of sympodial epiphytic orchids from America, Mexico and Argentina. The plants have either pseudobulbs or a fan of very thin leaves. They bear numerous attractive blossoms in various size and forms and are commonly called 'Golden Showers' and 'Dancing Ladies'.

The pseudobulbs are topped by one or more leaves which are small, soft, pencil like or very large, leathery and thick. Usually, single inflorescence is produced from a single growth or in some cases, two inflorescences may be produced. Inflorescences develop from the base of the pseudobulbs or from the axil of leaves. The flower size varies from $1 \mathrm{~cm}$ to $12.5 \mathrm{~cm}$ across. The flower colours are mostly shades of yellow and brown, and in some cases they are red, pink, magenta, green or white. In general, all three sepals are alike in size, shape and colour, although in some cases these vary. The two lateral petals are similar in size and shape while dorsal sepals are larger. Oncidium species are characterized by (i) presence of coloumn wings (ii) presence of complicated callus on the lip (iii) pseudobulbs with one or three leaves (iv) several basal bracts at the base of pseudobulbs.

\subsubsection{Species \& Hybrids (De, 2014)}

Tab. 9.7: Common Oncidium Species and Hybrids

\begin{tabular}{ll}
\hline Types & Species \& Hybrids \\
\hline Yellow Flowered & Oncidium splendidum O. lanceanum, O.spacealatum \\
Golden Shower type & $\begin{array}{l}\text { Aloha Iwanga Dogasima, Goldiana, Gower Ramsey, Golden Shower, Sum } \\
\text { Lai Who Jungle Queen, Taka H \& R, Sharry Baby Sweet Fragrance AM/AOS }\end{array}$ \\
White coloured & $\begin{array}{l}\text { Oncidium variegatum White } \\
\text { Popki Red, Irine Gleason Red, Vision Brownish Red, Catherine Wilson x New }\end{array}$ \\
Red coloured & $\begin{array}{l}\text { Calidonia Brownish Red } \\
\text { Robson Orchid Glad }\end{array}$ \\
Cream Coloured & O. lowianum hybrids \\
\hline
\end{tabular}




\subsubsection{Bigeneric Hybrids}

Aspasium = Oncidium $x$ Aspasia

Brassidium = Oncidium $\times$ Brassia

Miltonidium $=$ Oncidium $\times$ Miltonia

Odontocidium $=$ Oncidium $x$ Odontoglossum

Trichocidium $=$ Oncidium $x$ Trichocentrum

Oncidipilia $=$ Oncidium $x$ Trichopilia

\subsubsection{Trigeneric Hybrids}

Aliceara $=$ Oncidium $\times$ Brassia $\times$ Miltonia

Wilsonara $=$ Oncidium $\times$ Cochlioda $\times$ Odontoglossum

Colmanara $=$ Oncidium $\times$ Miltonia $\times$ Odontoglossum

\subsubsection{Tetrageneric Hybrids}

Withnerara $=$ Oncidium $\times$ Aspasia $\times$ Miltonia $\times$ Odontoglossum

\subsubsection{Interspecific Hybrids}

'Dark Tower', 'Ruby Frost', 'Sanddrinho', 'Barbara Ann', 'Himekogane', 'Peach Pie', 'Flamingo', 'Flower Fairy', 'Nutmeg Dancer’, 'Karukera Beauty’, 'Midnight Moon', 'Lemon Ice', 'Caribbean Stars', 'Ruby Jewell', Debonoir', 'Fragrance Fantasy', 'Red Fantacy'.

\subsubsection{Inter-varietal Hybrids}

'Volcano Gold', 'Dark Sun', 'Bright Night', 'Coral Gold', 'Golden Sun', 'Sundown', 'Sweet Sunset', 'Golden Bonanza', 'Dear Friend', 'Orchidom Happy’, 'Kulmura Gold', 'Aka Cacao', 'Music Shower', 'Summer Glow', 'Baby Breath', ' Island Gold', 'Kona Boy', 'Space Baby’, 'Millenium Gold', 'Golden Prince', 'Golden River', 'Sun Shade', 'Ash Hollow’, 'Private Dancer', ‘Green Valley', ‘Fragrant Red Barry’, ‘Golden Sunray’, 'Sungold', ‘Sharry Baby Dancing Doll', 'Sharry Baby Pink Lip', 'Sharry Baby ‘Tricolor’.

\subsubsection{Variety-Species Hybrids}

'Cameo Moonlight', 'Dusk', 'Jazzberry', 'Long Yellow', 'Orchidon Gold', 'Tokyo Fantacy', 'Panache Gold', 'Sarah Elizabeth Merritt', 'Barbie Doll', 'Elegant Dancer Pretty Lady’, 'Yellow Canary’, ‘Butterfly Profusion', 'Pacific Perfume’, ‘Copper Hills', Annabel', 'Forbes Island', 'Sweet Sugar' 


\subsubsection{Colmanara Hybrids}

Colm. 'Jungle Monarch', Colm. 'Wildcat', Colm. Wildcat 'Bobcat', Colm. Wildcat 'Cheetah', Colm. Wildcat 'Rainbow', Colm. Wildcat 'Red Star', Colm. Wildcat 'Tiger'.

\subsubsection{Medicinal Oncidium}

Oncidium cebolleta is reported to contain phenanthrene derivatives.

\subsubsection{Cultivation}

\subsubsection{Temperature}

The majority of species grow well in temperature between $25-30^{\circ} \mathrm{C}$ during daytime and $20^{\circ} \mathrm{C}$ during the night. A little bit of heat can be tolerated by the warmth tolerant Oncidium orchid hybrids if humidity and air movement are increased as the temperatures rise.

\subsubsection{Light}

Light needs can vary from bright to nearly full direct sun depending on the Oncidium orchid species and hybrids. Most Oncidium orchids will thrive with one to several hours of sun a day and a light intensity of 2500 foot candles. Generally, thicker-leaved plants, such as Tolumnias also known as "mule-ear" and "equitant" Oncidium orchids, can tolerate more light. Oncidium orchids in a greenhouse are best advised to make use of a shade cloth which can be anywhere from 30 to 50 percent shade, depending on the orchid plants. In the home, Oncidium orchids grow best in the east, south or west windows. Many types of Oncidium orchids will even grow under artificial light.

\subsubsection{Water and Humidity}

Most Oncidium orchid species and the Oncidium orchid hybrids prefer free compost that holds moisture rather than water. Water requirements vary with the type of orchid plant. Generally, Oncidium orchid plants with large fleshy roots or leaves require less-frequent watering than thin-leaved or thin-rooted plants. Watering should be thorough, and the medium should be allowed to dry at least halfway through the pot before watering again. This may be every 2 to 10 days depending on weather, pot size and material, type of orchid and type of potting medium. Plants not actively growing should be watered less. Humidity ranges should be between 50 and 60 percent. Many Oncidium orchids require less humidity than other orchids. Most greenhouses have adequate humidity and the Oncidium orchid can easily be kept well under those circumstances. Under indoor climate, Oncidium orchid plants survive better above moist 
pebbles in trays. If Oncidium orchids are grown in a shade house or garden outside, then they will require more frequent mistings to reduce the possibility of dehydration. Dehydration of Oncidium orchids is usually manifested as crinkled leaves.

\subsubsection{Feeding}

The Oncidium orchid is known to be a heavy feeder. The Oncidium orchid and its hybrids must be fed at half the recommended strength of most fertilizers once a week while the orchid plants are actively growing. A high nitrogenous fertilizer in spring is beneficial in terms of new growth and a balanced fertilizer during the summer and the winter keeps the Oncidium orchid in peak condition. During autumn, it is best to feed the Oncidium orchid with a high potash-based fertilizer to aid new flowering stems from the bulbs.

\subsubsection{Potting Mix and Repotting}

Potting of Oncidium orchids should be done when new growth is at about one-half mature stage. This is usually done in the spring. One can use fine-grade potting media with fine-rooted Oncidium orchid plants and coarser mixes with large-rooted orchid plants, and the standard size is medium grade. The Oncidium orchid should be positioned in the pot so that the newest growth is farthest away from the edge of the pot and allows the maximum number of new growths before crowding the pot. The roots of the orchid plant are spread over a cone of potting medium which is then filled in around the roots. The medium around the roots of the orchid plant is firmed with your fingers. The humidity is kept high and the potting medium kept dry until new roots form.

The Tolumnias, or equitant and mule-ear Oncidium orchids, as well as other fleshy-leaved or large-rooted orchid plants are easily grown on slabs of cork bark or tree fern or in pots filled with a coarse, well-drained medium such as charcoal, or even osmunda. This measure facilitates the necessary drying between water applications required by these Oncidium orchids; these orchids detest wet feet.

\subsubsection{Pests and Diseases}

The Oncidium orchid species is almost pest and disease free as fewer pests attack them. On rare occasions, Oncidium orchids get aphid infestation. This is observed usually with those orchids that are placed in open shade houses. 


\subsubsection{Post-harvest Management}

\subsubsection{Stage of Harvest}

Spikes are harvested when more than 80 percent of the flowers on the spikes are fully open on a spike length of $60 \mathrm{~cm}$ with many florets.

\subsubsection{Storage}

Cut flowers can be stored wet at 8 to $12^{\circ} \mathrm{C}$.

\subsubsection{Vase life}

Cut flowers last for 12 to 15 days in normal water.

\subsubsection{Preservatives}

8-HQC 200 ppm + 4\% sucrose; $\mathrm{AlCl}_{3} 100$ ppm + boric acid $500 \mathrm{ppm}+4 \%$ sucrose + aspirin $100 \mathrm{ppm}$ are commonly used preservatives for holding solutions.

\subsection{Paphiopedilum (Orchidaceae)}

\subsubsection{Introduction}

Paphiopedilums are most popular orchids because of their unique shape, colour and ease of cultivation. They are commonly called 'Slipper Orchids' and can be grown in windowsills, basements, Wardian cases, small greenhouses, in large commercial greenhouses, lathhouses and shade houses and can be grown in different climates. Paphiopedilum is a Greek word; 'Paphion' means an epithet for Aphrodite (the Goddess known as Venus to the Romans) and 'pedilon' meaning slipper. In India at least seven species have been reported so far. Paphiopedilums were originally introduced to England in the $19^{\text {th }}$ century.

Paphiopedilum venustum was the first species to flower in England in 1819, and subsequently other species like Paph. insigne, Paph. javanicum, Paph. purpuratum, Paph. barbatum, Paph. lowii and Paph. glanduliferum were introduced. The first hybrid of Paphiopedilum was flowered by John Domany of Messrs. It was Veitch who developed a hybrid and named it Paph. Harrisianum (Paph. villosum x Paph. barbatum). The second hybrid was named as Paph. Vaxillarium (Paph. barbatum x Paph. fairrieanum). More than 13,000 hybrids have been registered that are very attractive in colors, size and shapes. These are grown as pot plants or cut flowers. 


\subsubsection{Botanical Description}

Paphiopedilum consists of 50 species of terrestrial or lithophytic orchids distributed in the Himalayas, China, South East Asia, Indonesia and New Guinea. These orchids are stemless, pseudobulbless sympodial orchids with well developed leathery, elliptic lanceolate leaves clasping at the base. The flowers are borne singly or in few flowered racemes on a short to elongate inflorescence. The inflorescence is $60 \mathrm{~cm}$ tall and often purplish brown. The dorsal sepals are distinct with markings. The two lateral sepals are fused to form a vertical sepal. The lateral sepals are narrow and long with wavy margins. The petals are at right angles to the sepals and sometimes curve forward towards the lip.

\subsubsection{Hybrids}

\subsubsection{Natural Hybrids}

Paph. harrisianum: Paph. villosum x Paph. barbatum

Paph. vexillarium: Paph. barbatum $x$ Paph. fairrieanum

\subsubsection{Bigeneric Hybrids}

Phragmipaphiopedilum $=$ Phragmipedium $x$ Paphiopedilum

\subsubsection{Parents for Primary Hybrids}

Paph. viniferum, Paph. armeniacum, Paph. micranthum, Paph. malipoense

\subsubsection{Parents for Mottle Leaf Hybrids}

Paph. armeniacum, Paph. micranthum, Paph. bellatulum, Paph. concolor, Paph. superbiens, Paph. wardii

\subsubsection{Parents for Maudiae Hybrids}

Paph. sukhakulii

\subsubsection{Parents for Smallest Paphiopedilums}

Paph. bellatulum, Paph. concolor, Paph. godefroyae. Paph. niveum

\subsubsection{Parents for Multi-stemmed Flower}

Paph. charlesworthii, Paph. henryanum, Paph. spicerianum, Paph. tigrinum 


\subsubsection{Multi-floral or Strap Leafed Paphiopedilums}

Paph. rothschildianum, Paph. sanderianum, Paph. stonei, Paph. philippense, 'Prince Edward of York', Paph. 'Michel Koopuwitz', Paph 'Saint Swithin', Paph 'Mount Toro'.

\subsubsection{Fragrant Slipper Orchids}

Paph. delentii, Paph. malipoense, Paph. micranthum, Paph. armeniacum, Paph. 'Joyce Hasegawa', 'Paph. 'Lynleigh Koopwitz', 'Paph. 'Magic Lantern', Paph. 'Harold Koopwitz'.

\subsubsection{Hybrid Phragmipediums}

Phrag. 'Sorcerer’s Apprentice', Phrag. ‘Grande’, Phrag. 'Don Wimber', Phrag. 'Elizabeth March', Phrag. 'Hanne Popow’, Phrag. 'Jason Fischer', Phrag. 'Living Fire’.

\subsubsection{Interspecific hybrids}

'AI Rutel', 'Alexej', 'Hung Sheng Eye', 'Dungu Roth', 'Georges Morel', Memoria 'David Hanson', 'Caroline Hands', 'Armeni White', 'Magic Lantern', 'Malvic', 'Aaron Poock', ‘Chai-Ui Lady', 'Natasha Von Fox’, ‘Chiu Hua Dancer’.

\subsubsection{Intervarietal Hybrids}

'Big Tiger', 'Big Jaguar', Double Moon', 'Heavy Ken', 'Across World', 'Dark Shadow', 'Winter Vacation', 'World Records', 'Angel Dust', 'Tree of Crow', 'California Spirit', 'World Edition', 'Angel Lace', 'Red Delight', 'World Command', 'Mystic', 'Pulsar', 'Two Loves', 'Black Pepper'.

\subsubsection{Species-varietal Hybrids}

'Bubble Chocolate', 'Chunky Fairy', ‘Arthur Bell', 'Angel Drop', 'Baby Angel’, 'Black Beam', 'Doctor Mike Gothic Venture', 'Irish Lace', ‘ Night Leopard', 'Winter Passage’, 'Red Glory', 'Power Spice’, 'Professor Plum', 'Asian Sunshine’, 'Vintage Venus’.

\subsubsection{Cultivation}

\subsubsection{Light}

Generally, the slipper orchids grow on shallow humus or on rocks in forest areas where conditions are cool and plenty of shade is available to protect from direct sun light. Some of the species like Paph. villosum, Paph. parishii and Paph. lowii grow as epiphytes and on tree trunks of forest trees. Most of the paphs require lower light conditions in comparison to other orchids, but some species like $P$. randsii and $P$. phil- 
ippenense require higher light levels. High temperatures are detrimental for Paphiopedilums, and shade cloth roller blinds may be used in the glasshouse to control the temperature. The shade net can be drawn back during the cloudy season in summer and rolled up during winter season.

Paphiopedilum readily adapt to indoor conditions and can be grown successfully in artificial light. The optimum light for the growth of Paphiopedilum is between 600015000 lux (800-1200 foot candles). Direct sunlight is not ideal for slipper orchids.

\subsubsection{Ventilation and Humidity}

Paphiopedilums require good ventilation and high relative humidity particularly during summer months for the growth of leaves and roots and to minimize bacterial and fungal infection. The air movement helps to evaporate excessive water in the compost or potting medium. Therefore, the polyhouse should be equipped with exhaust fans of suitable size and misting systems to maintain proper humidity. The humidity can be maintained by fogging with a very fine spray, which allows tiny droplets of moisture to settle on the leaf surface thereby reducing the leaf temperature without saturating compost. In warm climates, evaporative coolers are essential for commercial glasshouses.

When the temperature decreases during the winter season, the humidity has to be decreased gradually. The optimum humidity for good growth of Paphiopedilums ranges between $65-75 \%$. Excessive humidity may cause fungal and bacterial infection. During extreme winter when temperature falls, heaters are essential to maintain proper temperature and humidity in the polyhouse. Under low humidity the maturing buds will show yellowing and dryness.

\subsubsection{Temperature}

Paphiopedilums can survive in a range of temperatures. The best temperature in polyhouses for good growth is between $15^{\circ} \mathrm{C}$ to $26^{\circ} \mathrm{C}$. However, some species may tolerate up to $36^{\circ} \mathrm{C}$. Decrease in night temperature is required for initiation of flowering particularly in $P$. rothschildianum and its hybrids. Paphiopedilums will generally tolerate lower than ideal temperatures provided the medium is dry. During hot summer, glasshouse fans are used to increase air movement with maximum ventilation and constantly introduced humidity. Shading is also used to minimize the temperature in the polyhouse.

\subsubsection{Containers and Compost}

Paphiopedilums generally prefer light friable humus, and well drained crevices and cracks. Two types of pots are available: clay and plastic pots. Clay pots are expensive, heavy and dry out quickly whereas plastic pots are light and inexpensive and extra drainage holes can be made easily. Plastic pots can be reused after washing in a 
bleaching solution followed by washing with water and proper drying. They prevent the potting media from drying out too quickly and should be used with an open, friable and airy mix.

The potting media should consist of coconut husk, expended clay, charcoal, peat or Sphagnum moss, perlite, vermiculite etc. Coconut husks are economical and are broken down rapidly by heat and fertilizers. In warmer climates, Sphagnum moss is widely used in clay containers which allow the mix to dry out without leaving the roots saturated. Charcoal can be used as an additive, but it attracts excess salts which is harmful for emerging roots. The most widely used potting mix contains equal part of peat and coarse grade perlite mixed with three parts of medium sized bark. A small amount of dolomitic lime is also recommended as an additive over the compost. The epiphytic Paphiopedilums are also mounted on tree fern slabs or cork rafts.

\subsubsection{Repotting}

In general, the repotting should be done once or twice a year after flowering. Whenever a plant becomes pot bound and looks unwell, repotting is recommended. The plant should be removed from the pot and the roots inspected. Dead roots are removed and the plant is repotted in the same or larger pot and care must be taken to avoid damaging roots, especially with plants that have live yellow tips. For repotting, damp compost is recommended and irrigation is not given to the newly repotted plants for at least two weeks. Additional humidity and fogging are necessary for rooting in newly potted medium. New roots are encouraged to grow in fresh potting medium. At this stage plants should be watered normally.

\subsubsection{Watering}

Rain water is supposed to be the best for paphs orchids but it is not always available. For newly potted plants the media should be allowed to dry, followed by watering. Paphiopedilums require more frequent watering during summer. In general, good humidity is maintained by misting. One can judge the amount of watering required by checking the dampness of the pot medium with one's fingers. Watering should be done as early as possible in the morning to ensure that excess water will evaporate and not remain on the foliage and in the growing tip overnight. It is advised that once a month the plant should be watered thoroughly so that excess mineral salts are leached out of the compost. It is also very important that the compost should not be allowed dry completely. If it is, misting should be done to maintain proper wetness.

\subsubsection{Fertilization}

Paphiopedilums lack pseudobulbs and do not have any reserve food materials for drawing nutrition intermittently. The media is supplemented with several granulated fertilizers at the time of potting. Fertilizers are required during the active vegetative 
growth stage of the plant. The basic fertilizers are highly diluted to a quarter or no more than half the strength suggested by the supplier.

During spring, nitrogen based fertilizer 30-10-10 (N:P:K) is applied to encourage growth followed by a general fertilizer (20-20-20) in the summer and then potash based fertilizers are applied (10-30-20) for flowering and hardening of the plants. After this application, water is applied thoroughly once a month to leach out any excess mineral salts, which would be detrimental to the health of the plant. During winter, a weak solution of general feed is applied.

\subsubsection{Propagation}

Vegetative propagation is the common method for multiplication of Paphiopedilums. It is necessary to ensure that the plant is divided equally, because inadequate division may be detrimental and allow attack by fungal and bacterial pathogens. Some species, particularly green strap-leaf species and succulent brachypetalums, do not survive after division, whereas the mottled leaf types can survive after division. Plants that have already flowered will often send out a new shoot when potted. Another method for multiplication of Paphiopedilums is selective breeding, as there is no proven technique of mericloning.

Paphiopedilum is also propagated by seeds in flasks by many growers. One flask contains about 25-30 seedlings, but growing these plants is a difficult task for small growers. Only those flasks that are vigorous, uniform with healthy roots and no fungal infection may be selected. The choice of flask and selection of stock depends on the experience, expertise and skill of the growers.

After the discovery of tissue cultures techniques during the 1960s, it was revolution in mass propagation of orchids and other crops. Today, all the ingredients of tissue culture are easily available from laboratory suppliers and the media can be prepared and sterilized within a very short time. Seeds are sterilized in bleaching solution and are then spread over solidified agar gels in the flasks. After few weeks to months whitish yellow bodies are formed which are called protocorm. Subsequently the flasks are transferred to growth chamber where temperature is maintained at about $21^{\circ} \mathrm{C}$. These flasks soon develop into tiny plantlets and are kept in the chamber for six to nine months until the plantlets are large enough to be removed.

To grow Paphiopedilum seedlings by seed culture is a costly affair for the small grower. However, a number of commercial laboratories offer flasking service. The best time to deflask the young plants is during spring or autumn.

\subsubsection{Pest and Diseases}

Among the orchids, Paphiopedilums are least affected by insect pests. Maintaining good hygiene in the polyhouse is the first step to manage the diseases and pests. 
Regular removal of the weeds and dead leaves plays an important role in minimizing disease and pest infestations of orchid polyhouses. Keeping clean floors free from algae and mosses will prevent snails and slugs. Plant benches may be cleaned and sprayed with liquid preventatives and slug pellets. Ants play an important role in bringing aphids, mealybugs and scale insects around plants. Therefore, by controlling ants, other pest problems can be minimized. Many pests can be removed manually; application of insecticides should be the last option. Before introducing the new plants into the glass house, they are thoroughly checked for pests and diseases, and proper quarantine procedures must be followed.

Spider mites and false spider mites cause damage to the leaves by causing pitting or silvery spots, depressions or punctures on the leaves. Heavy infestations are accompanied by white webbing on the underside of the leaves. By maintaining high humidity, spider mites can be controlled. The plant should be watered thoroughly before spraying miticides.

In Paphiopedilums, the bacterial diseases caused by Erwinia cypripedii and Pseudomonas cypripedii are most common. The infected area turns black or brown as the rot spreads. To control the disease, the infected plant should be separated immediately and the infected part may be removed by cutting, followed by treatment of the cut with sulphur. If the infection is extreme, the plant should be removed from the pot and the compost should be discarded, then the entire plant should be allowed to soak in Physan solution before repotting.

Sometimes crinkling and pleating of the leaves are reported, which are not very harmful. These symptoms are due to a lack of humidity at some stage of development of leaves. The pleating may arise due to genetic problems or from an incompatible breeding. Brown leaf tip or leaf tip burn usually indicates an excess of unleached mineral salts in the compost. The decomposing acidic, soggy compost is responsible for root tip burn, rotting and poor growth of roots.

\subsubsection{Post-Harvest Management}

Stage of harvest: 3 to 4 days after opening of flower

Storage: 0.5 to $3^{\circ} \mathrm{C}$ for 20 days

Vase life: 25 to 30 days

Preservatives: 8-HQC $200 \mathrm{ppm}+$ sucrose 2\%; $\mathrm{AgNO}_{3} 300 \mathrm{ppm}+$ sucrose $2 \%$

\subsection{Vanda (Orchidaceae)}

\subsubsection{Introduction}

The Vanda orchids are completely tropical and are easy to grow. Some species can be exposed to full sun. They are cross compatible with other genera like Ascocentrum, 
Aerides, Rhyncostylis, Neofinetia, Renanthera and even Phalaenopsis. All orchids having the same characteristics as the Vanda genus, are called vandaceous orchids and they are grouped together to form the Vanda Alliance. Genera like Vandas, Aerides, Ascocentrum, Renanthera, Rhyncostylis, Aranda, Mokara, Kagawara are included in the Vanda Alliance. Many of orchids under this group are called as 'Scorpion Orchids' or 'Spider Orchids'. They are ideal for hanging baskets, pots or tree logs. Leaf juice of Vanda coerulea is used against diarrhea, dysentery and external application for skin diseases. Leaf paste of Vanda teres is applied to reduce temperature in fever. Leaves of Vanda cristata are used as tonic and expectorant.

In Vanda tessellata, a paste made from the leaves is effective against fever. It is an ingredient of Rasna Panchaka Quatha. In Ayurvedic medicine, it is used in the treatment of arthritis and rheumatism. The leaf juice extract is used in the treatment of otitis media. The root is an effective against scorpion sting and bronchitis.

\subsubsection{Botanical Description}

Vanda consists of more than 70 species of monopodial epiphytic orchids distributed in India, China, The Himalayas, Sri Lanka, Philippines and throughout South East Asia. These commercial orchids are grown in Thailand, Singapore, Malaysia and Hawai.

They are diverse in vegetative and reproductive growth. Based on leaf characters they are grouped into four categories: strap shaped, terete, semi-terete and channeled (Tab. 9.8). The lip of strap shaped leaves is very irregular while the terete leaves are of pencil thickness. The inflorescence arises from the axil of the leaves in strap leaved orchids, whereas in the case of terete leaved orchids inflorescence emerge from the side of the stem of opposite leaf. The inflorescence is axillary, erect, and simple. The flowers are small to large, few to many, fleshy, heavy textured, long lasting and yellow, brown, purple, magenta, blue, and lavender in colour. The flower size varies from 2.5 to $10 \mathrm{~cm}$.

Tab. 9.8: Leaf Type in Vanda

\begin{tabular}{ll}
\hline Leaf types & Example species/varieties \\
\hline Terete & Vanda teres, V. ‘John Clubb’ V. 'Miss Joaquim' \\
Semi-terete & V. Emma van Deventer, V. Ruby \\
Channelled & Vanda sanderiana, Vanda lamellata \\
Strap & $\begin{array}{l}\text { Vanda coerulea, Vanda cristata, Vanda parviflora, Vanda coerulescens, } \\
\text { Vanda tassellata, V. stangeana, Vanda alpina, V. 'KS.SD', V. 'Prao Sky } \\
\end{array}$ \\
& $\begin{array}{l}\text { Blue', V. 'Pures Wax', V. 'RBSD Black', V. 'PAT D', V. 'Sansai Blue', V. 'Motes } \\
\text { Indigo', V. ‘Pakchong Blue', V. ‘Roberts Delight Blue’ }\end{array}$ \\
\hline
\end{tabular}




\subsubsection{Hybrids (De, 2014)}

\subsubsection{Natural Hybrids}

Vanda boumaniae, Vanda charlesworthii, Vanda 'Miss Joaquim'

\subsubsection{Bigeneric Hybrids}

Aeridovanda $=$ Aerides $x$ Vanda

Aranda $=$ Arachnis $x$ Vanda

Ascocenda $=$ Ascocentrum $x$ Vanda

Opsisanda $=$ Vanda $x$ Vandopsis

Renantand $a=$ Renanthera $x$ Vanda

Rhynchovanda = Rhyncostylis $x$ Vanda

Trichovanda $=$ Trichoglottis $x$ anda

Vandoritis $=$ Doritis $x$ Vanda

\subsubsection{Trigeneric Hybrids}

Aeridovanisia $=$ Aerides $x$ Luisia $\times$ Vanda

Burkillara $=$ Aerides $x$ Arachnis $x$ Vanda

Fujiora $=$ Ascocentrum $x$ Trichoglottis $x$ Vanda

Goffara = Luisia $x$ Rhyncostylis $x$ Vanda

Holttumara $=$ Arachnis $x$ Renanthera $x$ Vanda

Joannara $=$ Renanthera $x$ Rhyncostylis $x$ Vanda

Kagawara $=$ Ascocentrum $x$ Renanthera $\times$ Vanda

Leeara $=$ Arachnis $x$ Vanda $x$ Vandopsis

Moirara $=$ Phalaenopsis $x$ Renanthera $x$ Vanda

Mokara $=$ Arachnis $x$ Ascocentrum $x$ Vanda

Renanda $=$ Arachnis $x$ Renanthera $x$ Vanda

Trevorara $=$ Arachnis $x$ Phalaenopsis $x$ Vanda

Wilkinsara $=$ Ascocentrum $\times$ Vanda $\times$ Vandopsis

Yapara $=$ Phalaenopsis $x$ Rhyncostylis $x$ Vanda

Vascostylis = Ascocentrum $x$ Rhyncostylis $x$ Vanda

\subsubsection{Tetrageneric Hybrids}

Alphonsoara $=$ Arachnis $x$ Ascocentrum $x$ Vanda $x$ Vandopsis

Bokchoonara $=$ Arachnis $x$ Ascocentrum $x$ Phalaenopsis $x$ Vanda

Himoriara $=$ Ascocentrum $x$ Phalaenopsis $x$ Rhyncostylis $x$ Vanda

Isaora $=$ Aerides $x$ Ascocentrum $x$ Phalaenopsis $x$ Vanda

Knappara $=$ Ascocentrum $x$ Rhyncostylis $x$ Vanda $x$ Vandopsis

Okaara $=$ Ascocentrum $x$ Renanthera $x$ Rhyncostylis $x$ Vanda 
Robinara $=$ Aerides $x$ Ascocentrum $x$ Renanthera $x$ Vanda

Yusofara $=$ Arachnis $x$ Ascocentrum $\times$ Renanthera $\times$ Vanda

\subsubsection{Pentageneric Hybrids}

Knudsonara $=$ Ascocentrum $\times$ Neofinetia $\times$ Renanthera $\times$ Rhyncostylis $x$ Vanda

Macekara $=$ Arachnis $x$ Phalaenopsis $x$ Renanthera $x$ Vanda $x$ Vandopsis

Paulara $=$ Ascocentrum $\times$ Doritis $x$ Phalaenopsis $x$ Renanthera $\times$ Vanda

Sutingara $=$ Arachnis $x$ Ascocentrum $x$ Phalaenopsis $x$ Vanda $x$ Vandopsis

\subsubsection{Vanda Hybrids}

'Roberts Delight', 'Dr. Anek', 'Pakchong Blue', 'Miss Joaquim', 'Fuch's Delight', 'Lumpini Red', 'Motes Indogo Blue', 'Pat Delight', 'Rasri Gold', 'Samsai Blue', 'Adisak Smile', 'Robert Sorenson', 'Kasems Delight', 'Richard Brandon', Kultana Delight', 'Brigton's Pride', 'Hope’, 'Mark Lewis', 'Dr. Mahathis', 'Kultana Miami White', 'Kultana Violet', ‘Grand Lady’, ‘Fuch’s Midnight', 'Motes Nut Brown', 'Prayoon Delight’.

\subsubsection{Aranda Hybrids}

'City of Singapore', 'Hilda Galistan', 'Urmila Nandey', 'Christine', 'Thailand Sunspot', 'Millenium Dawn', 'Broga Giant', 'Salaya Red', 'Propine White', 'Propin Spot', 'Lueng Cholburi', 'Ishbel Manisaki', 'Baytown', 'Chao Praya Blue', 'Chao Praya Dot Com', 'Chao Praya Beauty', 'Ethan Pride’, 'Taksari Chandrabir'.

\subsubsection{Ascocenda Hybrids}

'Carol Belk', 'Renuka Angle', 'Joyce Bevins', 'Adisak Blue', 'Renu Gold', 'Tipi Blue Boy’, 'Bobs Fortune', 'Rubychai’, Shah Rukh Khan', Yang Sophia Firuz', 'Abdul Ghani Othman', 'Chunika', 'Fuch's Star', 'Kultana White', 'Golden Peace', 'Lani Beauty', 'Mahogany Gem', 'Copper Pure', 'Pokey Dot'.

\subsubsection{Mokara Hybrids}

'Madam Panne', 'Bangkok Gold', 'Chao Praya Gold', 'Chark Kuan Orange', 'Chark Kuan Pink', 'Kelvin Red', ' Kelvin Orange’, 'Walter Ouame’, 'Jitti Orange', 'Happy Beauty', 'Margaret Thatcher', 'Sarita Gold', 'Laura Bush', 'Winny Burang', 'Gladys Oumae', 'Denis Child', 'Ratchaburi Blue', 'Lion's Gold', 'Chao Praya Sunrise', 'PakKred', 'Golden Rooster', 'Jasso's Pride', 'Chao Praya Classic', 'Chao Praya Spots', ‘ Calypso', 'Bota Gold'. 


\subsubsection{Kagawara Hybrids}

'Red Lava Orange', 'Mist', 'Christie Low Redland', 'Broga Cemerlang', 'Chao Praya Fantasy', 'Curtis Lutchman', 'Emily Kavita Rajah', 'Diinesh Gold', 'Lion’s Flame', 'Irene Hew’, ‘Bukit Timah', 'Sandy Gold'.

\subsubsection{Vascostylis Hybrids}

'Ique Pink', 'Kruewan', 'Banjong Jasmine', 'Mishima Lime', 'Vanity Fair', 'Firuz', 'Pine Rivers', 'Banjong Elite’, 'Pichtawit Gold', 'Chao Praya Lime’, 'Lanna Rosy’, 'Jeans Delight', 'Bay Sapphire', 'Spring Hill'.

\subsubsection{Aeridovanda Hybrids}

'Bensiri', ‘Noreen', ‘Early Bird', 'Shiv Sidhu', 'New Dawn', 'Harrison Luke Somsri Sunlight'.

\subsubsection{Cultivation}

\subsubsection{Light}

All Vanda orchids require high light levels. Strap leaf Vandaceous orchids require 60-65\% shade whereas terete or semi-terete vandas need more light and require 50\% shade. On average they require a light intensity of 4000 foot candles.

\subsubsection{Temperature}

The Vanda orchid prefers warm temperatures in summer and winter. They are highly susceptible to cold and frost. In cooler regions, the orchid plants will go into a dormant state during winter. Cylindrical Vandas require a minimum temperature of $16-17^{\circ} \mathrm{C}$ at night during winter, and a maximum of $30-32^{\circ} \mathrm{C}$ in the summer. Flat leaved vandas need a winter night temperature of $10-12^{\circ} \mathrm{C}$ and a summer day time temperature of $22-25^{\circ} \mathrm{C}$ They are capable of tolerating higher and lower temperatures for short periods only.

\subsubsection{Propagation}

Easily propagated by cuttings of the shoots along with roots or air layerings. Rapid large scale multiplication is possible through tissue culture.

\subsubsection{Watering}

Vandaceous plants love good quality water. Being a monopodial, the plants cannot retain water for any great length of time. It is advisable at all times to water these 
plants as early in the morning as possible, so that the foliage of the plant is dry by noon. Orchids do not appreciate being wet and cold, so water your plants in the winter time only on bright and clear mornings as necessary. Adult plants are watered once a week in the winter time and every day during summer.

\subsubsection{Fertilization}

All Vandaceous orchids are heavy feeders. During the growing period from the beginning of September to the end of March, the adult plants are fed once a week as follows: For two weeks we use a well balanced fertilizer (30:10:10) and the following week we use a low nitrogen fertilizer (10:30:20). The young seedlings are fed once a week; one can use a well balanced fertilizer (30:10:10) and the following week using a low nitrogen fertilizer (10: 30: 20).

During the dormant period when the weather starts getting cooler and the daylight hours shorten, the food to plants is reduced. Adult plants are fed only once a fortnight with a low nitrogen fertilizer in order to keep the velamen on the root system plump. The young seedlings are fed only once a fortnight, rotating a balanced fertilizer with a low nitrogen fertilizer as mentioned above.

\subsubsection{Potting Media}

Freshly deflasked seedlings are potted into a fine mix in community pots, and the larger plants (from flask) are potted directly into $50 \mathrm{~mm}$ tubes using the same mix. When the plants have outgrown their $50 \mathrm{~mm}$ tubes, they are either potted into $10-12 \mathrm{~cm}$ black plastic baskets or $15 \mathrm{~cm}$ clay pots which have extra holes in the sides.

The mix used in $15 \mathrm{~cm}$ pots is 50\% good quality treated bark, 30\% larger chunks of cocochips and $20 \%$ brick pieces. In the baskets or clay pots, one can put extra coarse bark and cocochips to support the plants until the roots have gripped the container. This assists Vandaceous orchids by providing plenty of good air circulation around the root system. They do not like to have wet feet especially during prolonged rainy or cold weather when they can get bacterial soft rot.

\subsubsection{Insect -pests and Diseases}

Fungal and bacterial diseases cause collapse of the plant's tissues, frequently with a water soaked appearance. Bacterial infection may attack the leaves, the stem or the root system. These diseases require high humidity to survive. Some occur at high humidity and low temperatures, while other types are not activated until the temperatures are relatively high. These diseases can be discouraged by watering orchids as early as possible in the morning so when the temperature reaches its peak, the plants dry up and will remain so as the temperature falls at night. 
Fungal and bacterial problems can be kept to a minimum with good sanitation, good air circulation around the plants, and regular spraying with a preventative fungicide to protect the plants against infection.

Mancozeb or Dithane (0.2\%) is also used periodically if required, for instance after prolonged rainy weather. Before the onset of winter (beginning of May) a mixture of Mancozeb and Spraytech Oil is sprayed on the plants. Infections such as bacteria can enter the plants through injury to the root system and then the plant is susceptible to Fusarium Wilt. The affected plants start to drop the lower leaves. Spraying with Mancozeb $(0.2 \%)$ or Zineb $(0.2 \%)$ controls the disease. Vandaceous orchids are almost free from pests and insects. Occasionally scale or cockroaches may attack, causing a widespread infection in the shade-house. If required, spray with a mixture of Diazinon and White Oil for scale or Diazinon to prevent cockroaches.

\subsubsection{Post-harvest Management (Bhattacharjee and De, 2005)}

\subsubsection{Stage of harvest:}

Spikes are harvested when all flowers are already open, depending on types 10 to 16 flowers on a stem length of $50-60 \mathrm{~cm}$.

\subsubsection{Storage}

Cut flowers are wet stored at 8 to $13^{\circ} \mathrm{C}$.

\subsubsection{Vase life}

Cut flowers last for 14 to 15 days in normal water.

\subsubsection{Preservatives}

$\mathrm{AgNO}_{3} 30 \mathrm{ppm}+$ sucrose $1.5 \%$ is commonly used preservatives in holding solutions for enhanced vase life of cut flowers. 